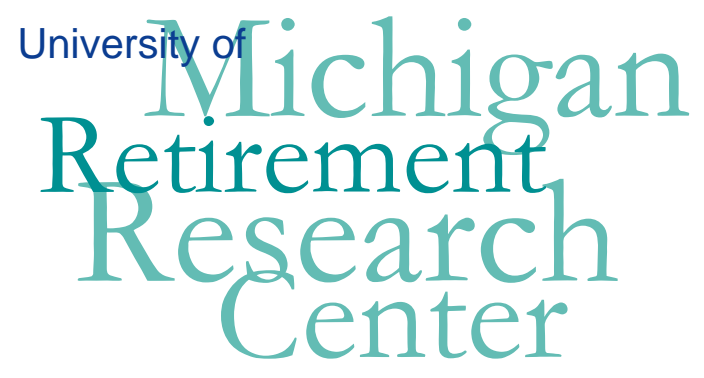

Working Paper

WP 2009-202

\title{
Social Security Rules and Labor Force Participation of Older Workers: Evidence from Chile
}

Alejandra Cox Edwards and Estelle James

\begin{tabular}{|l|l|l|l|l}
\hline $\mathrm{M}$ & $\mathrm{R}$ & Project \#: UM08-23
\end{tabular} 


\title{
Social Security Rules and Labor Force Participation of Older Workers: Evidence from Chile
}

\author{
Alejandra Cox Edwards \\ California State University-Long Beach \\ Estelle James \\ Hudson Institute \\ April 2009 \\ Michigan Retirement Research Center \\ University of Michigan \\ P.O. Box 1248 \\ Ann Arbor, MI 48104 \\ http://www.mrrc.isr.umich.edu/ \\ (734) 615-0422
}

\section{Acknowledgements}

This work was supported by a grant from the Social Security Administration through the Michigan Retirement Research Center (Grant \# 10-P-98362-5-04). The findings and conclusions expressed are solely those of the author and do not represent the views of the Social Security Administration, any agency of the Federal government, or the Michigan Retirement Research Center.

\section{Regents of the University of Michigan}

Julia Donovan Darrow, Ann Arbor; Laurence B. Deitch, Bingham Farms; Olivia P. Maynard, Goodrich; Rebecca McGowan, Ann Arbor; Andrea Fischer Newman, Ann Arbor; Andrew C. Richner, Grosse Pointe Park; S. Martin Taylor, Gross Pointe Farms; Katherine E. White, Ann Arbor; Mary Sue Coleman, ex officio 


\title{
Social Security Rules and Labor Force Participation of Older Workers: Evidence from Chile
}

\author{
Alejandra Cox Edwards and Estelle James
}

\begin{abstract}
Recent research has argued that incentives stemming from social security systems influence the worker's decision to retire. The experience of Chile, which radically changed its system in 1981, offers an opportunity to test this hypothesis. The new system tightened access to early pensions, replaced an actuarially unfair defined benefit plan with an actuarially fair defined contribution plan, exempted pensioners from the pension payroll tax and allowed widows to keep their own pension in addition to their survivor's benefit. Although the old system is being phased out, since 1981 the two systems have co-existed. Using probit analysis of the behavior of a retrospective sample of new and old system affiliates, we estimate the impact of the new social security rules on the probability of dropping out of the labor force, for older workers. We find large effects. Age of pensioning has been postponed. Labor force participation is much higher among affiliates of the new system compared with the old, especially for pensioners and women. This is not simply due to selection: Aggregate participation rates have increased as the new system's share of total affiliates has risen.
\end{abstract}




\section{Social Security Rules and Labor Force Participation of Older Workers: Evidence from Chile}

Labor force participation of older men has declined in many countries during recent decades. This has decreased the available supply of human capital and increased the fiscal problems of pension programs. A considerable literature has developed on the extent to which incentives stemming from social security systems have contributed toward this decline or can help reverse it. The experience of Chile, which radically changed its system in 1981, offers an opportunity to test whether large system changes produce large labor supply changes. In a previous study based on changing behavior of successive cohorts that were increasingly exposed to the new system, we found that younger cohorts postponed pensioning and had a higher labor force participation rate than older cohorts-evidence that increasing new-system membership raised work propensities (Edwards and James 2008). This paper revisits this topic using individuallevel data. Unlike the previous paper, which focused on men, we are able to include women in the current analysis. We are not aware of any other study addressing this impact of the Chilean reform. ${ }^{1}$

Prior to 1981 Chile had a traditional pay-as-you defined benefit (DB) system that included disincentives to work among older individuals, similar to those found in many European countries today. Contribution rates were high, allowable pension ages low and benefits didn't change commensurately with incremental contributions or postponed pensions. Workers had strong incentives to start their pensions as soon as possible because this maximized their lifetime net benefits, and labor force participation dropped 
dramatically when pensions started. This changed with the 1981 reform, which reduced the pension payroll tax, replaced the DB system with a defined contribution (DC) system and included several other important changes expected to raise the labor force participation rates of older individuals. Workers then in the labor force had a choice between staying in the old system or switching to the new system. New entrants to the labor force had to join the new system. Thus, for some time the two systems have coexisted, although the old system is gradually being phased out and an increasing proportion of worker belonged to the new system after 1981.

In this paper we focus on differences between the new and old systems during the period when they co-existed. We look, in particular, at the behavior of different subgroups that were affected differentially by the complex rule changes. We hypothesize that: (1) the reduction in pension payroll tax and move toward greater actuarial fairness increased incentives for non-pensioners to voluntarily postpone pensioning and work longer - but we expect this effect to be relatively small; (2) the elimination of restrictions on continued work for pensioners and their complete exemption from the pension payroll tax increased work incentives for pensioners even more; (3) tighter early pension preconditions increased the proportion of older individuals required to remain as nonpensioners who had to work longer because of liquidity constraints; (4) the increase in years of eligibility (from 10 to 20 years) required for the minimum pension guarantee (MPG) further encouraged low earners (disproportionately women) to postpone pensioning and withdrawal from the labor force; and (5) married women and widows were encouraged to work longer because they can keep their own pension in addition to the survivor's benefit, whereas previously they faced a $100 \%$ tax on their own pension in order to get survivors' benefits. 
To carry out this analysis we draw on a retrospective sample of new and old system affiliates conducted in 2002, 2004 and 2006 (ESP 2002, 2004 and 2006), which gives us their work histories and demographic data going back to 1980 . We use probit analysis of the behavior of a panel of about 6000 older men and women who were born 1931-56 and whose histories were observed retrospectively for the period 1980-2006. We study their pension and work behavior at ages 50-70. Our main findings: Labor force participation rates rose dramatically and pension age was postponed among new system affiliates. This holds for most sub-groups but it is strongest for pensioners and women. Non-pensioners work longer than pensioners but their participation rates did not increase as much so the gap narrowed after the reform. These behavioral effects of the reform remain after controlling for many individual and time-specific co-variates.

The main challenge to these results is the possibility of selection and maturation bias. Individuals with greater work propensities may have chosen the new system, which rewards marginal work more than the old system. To analyze whether selection is driving these results, we contrast the behavior of the main sample with the behavior of earlier and later cohorts that had little or no system choice because they were too old or too young in 1981 to choose. Our results are unchanged when the low-choice cohorts are added. In addition, average age-adjusted participation rates for both systems combined increased over time as the proportion of new-system affiliates increased, so we are not simply observing a rearrangement of people with unchanged behavior. Both these results suggest that selection bias is not driving the new-system effect. (Also see Edwards and James 2008). The latter result also indicates that the new-system effect is not an illusion caused by differential maturities of the two systems. 
Part 1 reviews the literature on the impact of social security system rules on retirement age and develops our hypotheses about work and pension incentives in the new versus old Chilean schemes. Part II describes our data set, probit model, reform indicators and other variables. Part III estimates the impact of the reform on the probability of becoming a pensioner and of dropping out of the labor force for older men and women. The Conclusion highlights lessons for other countries.

\section{What do Theory and Empirical Evidence Suggest about Retirement Choice? Retirement behavior and pension systems: theoretical framework}

An adaptation of the options value method of measuring marginal retirement incentives used by Gruber and Wise (2004) is the starting point for our analysis of the impact of the Chilean reform. According to this model, workers calculate the expected present value (EPV) of incomes for all future potential retirement dates. They postpone retirement beyond the earliest eligible age (t) to some future date (r), if the utility from the incremental EPV of net wages plus incremental lifetime benefit growth from work between $\mathrm{t}$ and $\mathrm{r}$ exceeds the utility from incremental leisure between $\mathrm{t}$ and $\mathrm{r}$.

$$
\mathrm{U}\left[\mathrm{EPV} \sum(\mathrm{W}-\mathrm{C})^{\mathrm{tr}}+\operatorname{EPV} \sum(\mathrm{B}(\mathrm{r})-\mathrm{B}(\mathrm{t}))\right]>\mathrm{U}\left(\mathrm{L}^{\mathrm{tr}}\right)
$$

where:

$$
\begin{aligned}
& \operatorname{EPV} \sum(\mathrm{W}-\mathrm{C})^{\mathrm{tr}}=\text { exp. net wages (gross wages-contributions) between } \mathrm{t} \text { and } \mathrm{r} \\
& \operatorname{EPV} \sum(\mathrm{B}(\mathrm{r})-\mathrm{B}(\mathrm{t}))=\text { exp. added benefits from postponing retirement from } \mathrm{t} \text { to } \mathrm{r} \\
& \mathrm{U}\left(\mathrm{L}^{\mathrm{tr}}\right)=\text { discounted utility of incremental leisure between } \mathrm{t} \text { and } \mathrm{r}
\end{aligned}
$$

For many individuals, their social security wealth $\left(\mathrm{EPV} \sum \mathrm{B}\right)$ in mandatory systems exceeds the amount they would have saved voluntarily. This increases the relative marginal value they place on leisure, hence their desire to stop work earlier than they would have otherwise. However, work rarely stops before the pension starts because of 
liquidity constraints. This wealth effect on leisure preference is one reason workers start the pension at the earliest eligible age and stop work at the same time, in any system that mandates postponed consumption.

Gruber and Wise focus on another factor that exists in many systems--the incentive effect on retirement stemming from the absence of marginal actuarial fairness. In a system that is actuarially fair at the margin, incremental contributions yield added monthly benefits with an equivalent EPV and postponing the pension raises monthly benefits enough to hold $\mathrm{EPV} \sum \mathrm{B}$ constant so

$$
\operatorname{EPV}\left[\sum(\mathrm{B}(\mathrm{r})-\mathrm{B}(\mathrm{t}))-\sum \mathrm{C}^{\mathrm{rt}}\right]=0
$$

(see Disney, Queisser and Whitehouse 2006). In that case, equation (1) collapses into equation (3), and work continues so long as:

$$
\mathrm{U}\left[\operatorname{EPV} \sum(\mathrm{W})^{\mathrm{tr}}\right]>\mathrm{U}\left(\mathrm{L}^{\mathrm{tr}}\right)
$$

In contrast, in an actuarially unfair system this equality between incremental benefits and contributions does not hold. Gruber and Wise (1999 and 2004) show that DB systems are often actuarially unfair. Specifically, the EPV of incremental benefits $\left(\sum(\mathrm{B}(\mathrm{r})-\mathrm{B}(\mathrm{t}))\right.$ is less than the EPV of incremental contributions for those who work longer, creating a tax wedge between gross and net remuneration and leading work to stop in accordance with equation (1), sooner than it would under equation (3). Moreover, work is often restricted or penalized once the pension starts. As a result of these system rules, two potentially separable decisions--starting the pension and stopping work- are de facto linked, a single term-retirement--is commonly used to denote them, and workers retire at the earliest eligible age. As government policies have reduced the earliest eligible pension age, increased the tax wedge and mandated the growth of 
pension wealth, retirement age has dropped in many countries. Chile fit this picture before 1981.

\section{Retirement rule changes in the Chilean reform and how they affect behavior}

The Chilean pension reform was a complex package, with many rule changes. Starting with a system that charged a high payroll tax, that was decidedly unfair actuarially, that tied the work and pension decisions together and made early retirement easy, the reform moved toward lower tax rates, payroll tax exemption for pensioners, fewer work restrictions, greater actuarial fairness, tighter conditions for early retirement and MPG eligibility and more pro-work policies for women.

Moving toward lower payroll taxes and actuarial fairness by replacing $D B$ with $D C$. The old Chilean system consisted of several sub-systems, with different details but similar general outlines. In the largest sub-system, Servicio Seguro Social (SSS), the payroll tax for pensions was $23 \%$, with another $10 \%$ for other social insurance, bringing the total to $33 \%$. $^{2}$ The monthly defined benefit was $50 \%$ of the base wage for the first ten years of service but only $1 \%$ additional for each year thereafter, until a $70 \%$ ceiling was reached, at which point the incremental benefit became 0 . Postponing the pension did not increase the benefit nor did greater life expectancy decrease it. Benefits were not automatically price-indexed, but ad hoc increases occurred. As in many other countries with traditional systems, workers were likely to start the pension and stop work as soon as they became eligible for the pension.

In the new system, each worker is required to contribute $10 \%$ of his or her wages to an individual DC account, plus another $2-2.5 \%$ for administrative fees and disability and survivors insurance, totaling about half the old rate. ${ }^{3}$ Contributions are invested in a pension fund (AFP) of the worker's choice and accumulate a market rate of return that 
averaged over $10 \%$ real per year for the first 20 years of the system. Payouts must take the form of price-indexed annuities or gradual withdrawals over the person's lifetime. Most retirees purchase annuities, delayed annuitization increases the monthly pension commensurately, and annuities have had a money's worth ratio of $100 \%$ or more (James, Martinez and Iglesias 2006). Thus, the new system is actuarially fair in the sense that the EPV of lifetime benefits equals the EPV of lifetime contributions and incremental contributions or postponed pensioning are rewarded with equivalent expected real benefits, discounted at the risk-free market rate of return. This reduction in explicit and implicit taxes might lead to delayed pensioning and longer work, on a voluntary basis.

Eliminating work restrictions and payroll tax for all pensioners. In the old system, continued work in the public sector was not allowed once the worker started the pension. Private sector work was allowed, but often workers had to change jobs upon pensioning. Moreover, contributions had to continue so long as the individual worked, even if he had already pensioned and got little or no additional benefit. In contrast, in the new system pensioners can continue working, with no restrictions. They are totally exempt from the pension payroll tax after pensioning. In effect, this makes the system fully actuarially fair with respect to continued work by pensioners. Their nominal net wage rises by $14 \%(12.5 / 87.5)$ after pensioning (or by $7 \%$ if the implicit tax component was $50 \%$ ). This exemption for pensioners should increase their incentive to work.

Tightening the conditions for early pensioning. In the old system, normal pension age was 65 for men, 55-60 for women, but earlier retirement based on length of service, disability or for other reasons was common. ${ }^{4}$ In the new system, normal pension age is 65 for men, 60 for women, and early pensioning was not permitted before 1988. Starting in 1988 it was allowed, but subject to tight restrictions. Until 2004 the retirement 
accumulation had to provide a benefit that was at least $50 \%$ of the worker's own average wage and $110 \%$ of the minimum pension guarantee (MPG), for pensioning prior to $60 / 65$. Recently these were raised to $70 \%$ and $150 \%$, respectively (Edwards and James 2006; James, Martinez and Iglesias, 2006). ${ }^{5}$ Note that in the new system retirement savings are converted into pensions on actuarially fair terms. Therefore this constraint will become more binding over time as expected longevity rises, thereby reducing monthly payouts unless pension age is postponed. The new early retirement rules may be especially binding for individuals with less education, whose own-pensions are closer to the MPG.

The minimum pension guarantee. The new and old systems both contain a minimum pension guarantee (MPG). If an eligible worker's own-pension is less than the MPG, the government tops it up to bring it to the floor-so low-earners have a strong incentive to become eligible. ${ }^{6}$ Once they are eligible for the MPG top-up, any further wage or own-pension for low earners replaces government dollars one for one- $\mathrm{a}$ strong disincentive for them to work. This applies in both systems.

However, the new and old systems have different eligibility requirements - 20 years of contributions in the new system, only 10 years for women and some men in the old system. Also, in the new system the MPG is reduced for early pensioners. Therefore, new-system affiliates whose own-pensions will be in the vicinity of the MPG have a strong incentive to postpone pensioning and work longer, up to the 20 -year point, in order to qualify. ${ }^{7}$

This data set does not inform us of the worker's retirement accumulation, so we are unable to identify those whose potential pension is in the neighborhood of the MPG. Also, the retrospective employment histories do not go back beyond 1980 so we do not know which individuals are near, far above or far below the 20-years required for 
eligibility. However, we know that women affiliates and men with less than secondary education have relatively low earnings, hence are probable candidates for the MPG and will benefit from passing the 20 -year threshold. These are the same groups that will have a hard time meeting the new system's early retirement pre-conditions. The tighter MPG eligibility requirements constitute an additional reason why these groups may postpone pensioning and work longer in the new system than the old.

Treatment of survivors' benefits for women. Both in the new and old systems women whose husbands die receive survivors' benefits. (Until 2008 men were not eligible for survivors' benefits unless they were financially dependent on their wives, because they were disabled). In the old system this was provided through the DB system and the widow could not keep her own pension in addition to the survivors' benefit; she had to give up one, usually her own, which was smaller. In the new system, survivors' benefits are provided through private group insurance contracts while the spouse is working and the required purchase of a joint pension when he retires. Perhaps because these are not viewed as being financed by the common pool, widows are permitted to keep the survivor's benefit in addition to their own. The $100 \%$ tax on own-pension that most women previously faced was eliminated, which should encourage their work.

\section{Hypotheses about how these rule changes will change behavior}

In the new system we must distinguish between two dimensions of retirement: starting the pension and stopping work. Tightened early retirement pre-conditions lead to postponed pensioning because of binding constraints. In addition, if workers regard the new system as actuarially fair, they will be indifferent between postponing the pension versus starting it, so long as they are savers; thus some persons who want to save will choose to remain non-pensioners longer than they did previously. 
However, if a tax wedge still exists between net and gross remuneration, many individuals will continue to start the pension as early as possible, as they did before. We expect that such a wedge may remain, albeit smaller than before. Many individuals (especially those with little voluntary saving) may not regard the new system as completely fair, because their own subjective discount rates for time or risk do not coincide with market rates. ${ }^{8}$ In general, restrictions on saving rate, investments and payouts are inevitable in mandatory defined contribution social security systems, yet heterogeneity among workers implies varying savings-consumption and risk-return preferences. The resulting divergence between subjective and market discount rates for time and risk maintains a tax wedge between incremental contributions and benefits and thus between gross and net remuneration from work, even in systems that are supposedly actuarially fair. It has been estimated that, on average, a 50\% implicit pension tax remains in Chile. ${ }^{9}$ This would mitigate the willingness to voluntarily postpone pensioning and withdrawal from the labor force as a result of the move toward actuarial fairness. ${ }^{10}$

After pensioning, work can continue without contributions, so the wedge between net and gross wage disappears and the work decision depends solely on gross wageleisure trade-offs.

We therefore expect to find the following new-system effects on participation rates of older workers:

1. The new system may increase participation rates of non-pensioners due to increased actuarial fairness. That is, we may observe a behavioral shift from equation (1) to equation (3). However, this effect may be small because the system remains incompletely fair to many workers. 
2. The new system will increase participation rates of pensioners, due to the removal of restrictions on their right to work and their exemption from the pension payroll tax. Equation (3) applies in these cases.

3. The new system will postpone age of pensioning due to tighter early retirement pre-conditions. This will apply particularly to individuals with less education, who will have the hardest time meeting the new system's requirements. Since non-pensioners have higher participation rates than pensioners because of liquidity constraints, this will further increase participation rates in equations that do not control for pension status. The newsystem impact on age of pensioning should fall at age 60 for women, 65 for men, at which point they are eligible to retire regardless of accumulation.

4. Men with low education and women, who are low earners, may also work longer before and after pensioning in order to meet the new system's 20 -year requirement for eligibility for the MPG.

5. Widows and women more generally are encouraged to work longer because the $100 \%$ tax on own-pensions that they previously faced, as (potential and actual) recipients of survivors' benefits, has been removed.

One purpose of this paper is to compare the effects of rules that change incentives versus constraints. For example, actuarial fairness and tighter early retirement preconditions might both lead to postponed pensioning, but if the latter dominates, postponement should become much weaker after age 60/65, when the constraints disappear. Another purpose is to compare the new-system effects of the reduction in implicit taxes due to actuarial fairness for non-pensioners versus the elimination of explicit taxes for old age and survivors' pensioners. If the latter effect is stronger, we expect pensioners and women to exhibit the largest new-system effects on participation 
rates. A third object is to compare impacts on men and women, who may be affected differentially by these rules.

\section{Previous empirical studies on the U.S. and other countries}

During the past decade a large empirical literature has developed to investigate the falling labor force participation rate among older men and the impact of pension system wealth and rules. The benchmark studies by Gruber, Wise and their colleagues (1999 and 2004) measure retirement incentives facing older men across eleven industrialized countries and through time. They show large work disincentives stemming from defined benefit social security systems, and the greater these disincentives the less likely individuals are to postpone retirement. Borsch-Supan (1998) finds similar effects for Germany and other European countries. A recent study by Lluberas (2007) finds that workers in DC plans expect to retire later than those in DB plans. Butler, Huguenin and Teppa (2004) attribute the falling labor supply of older men in Switzerland to the maturing of generous mandatory pension plans, which increased their pension wealth. Workers spend this wealth on longer periods of retirement leisure.

Several studies use U.S. data to examine the impact of social security wealth, implicit tax incentives and early retirement rules. They find small to modest effects that vary by income and marital status, and a discontinuous drop in labor force participation at the earliest and normal age of eligibility for pensioning (Hurd 1990, Fields and Mitchell 1984, Burtless and Moffitt 1986, Stock and Wise 1990, Krueger and Pischke 1992, Blau 1994, Gustman and Steinmeyer 1985, Anderson, Gustman and Steinmeyer 1999, Coile and Gruber 2001). Song and Manchester (2006) find that the removal in 2000 of the retirement earnings test (which reduced benefits for pensioners who earned wages) increased work propensities substantially, especially among older individuals in the 
higher income percentiles. Friedberg (2007) summarizes various explanations for the recent trend toward delayed retirement in the U.S. (much smaller than that in Chile), including the elimination of the penalty for working while collecting social security benefits and the increased increment from delaying the start of benefits. Pang, Warshawsky and Weitzer (2008) find that increases in pension and other wealth raise the probability of retiring while the shift from employer-sponsored DB to DC plans delays retirement.

A previous study by the authors (Edwards and James 2008) used data from 47 years of repeated cross sections to examine changes in pension probabilities and labor force participation rates in Chile before and after the reform. The raw data show sharp reduction in pension probabilities and sharp increases in pensioner's labor force participation rates among older men in the post reform years. Using probit analysis to isolate reform-related changes, with the person's birth cohort proxying the probability of new-system affiliation, we estimate an increase of 16 percentage points in the participation rates of cohorts that recently entered the 50-59 age range, and 17 percentage points for ages 60-64, relative to pre-reform rates. Part of this increase is due to higher work propensities among pensioners and another large part is due to tighter early retirement restrictions that constrain individuals to postpone pensioning. The impact of actuarial fairness on the behavior of non-pensioners was ambiguous.

The previous paper covered a long time period and enabled us to study cohort changes in participation rates over time, both before and after the reform. This approach had the advantage that it avoided issues of selection into the new system, since it measured changes in the behavior of cohorts that had mixed affiliation. However, it did not lend itself to analysis of individual-level behavior since it did not tell us which system 
the individual was in, what kind of pension he got (old age, disability or survivors), or when he retired. Because many women receive survivors' pensions, which may imply different incentives and lead to different behavior from old age pensions, we were not able to analyze women in the previous paper. The current data set covers a smaller period of time and has data on work histories only since 1980, but provides richer individuallevel data, including system affiliation and type of pension. Therefore, it enables us to compare the work behavior of old and new system members, including both men and women, after the reform.

\section{Data, Probit Model and Reform Indicators}

To carry out this analysis, we use a recent restrospective survey of new and old system affiliates (EPS2002, 2004 and 2006). EPS is a large retrospective survey, with about 20,000 observations, that was conducted in 2002, 2004 and $2006 .{ }^{11}$ It is representative of the working age population, including new and old system affiliates and those who are not affiliated to any system, between 1981 and 2006. Through retrospective questions, the survey establishes which periods the person was working, unemployed or out of the labor force during 1980-2006, to which system he or she was affiliated, if and when the individual was pensioned, what type of pension he or she receives (old age, survivors or disability), pension date and amount (if relevant), and data on schooling, health, gender and marital status. We are interested in the propensity of these individuals to become old age pensioners and to withdraw from the labor market, and whether these propensities are different under the new and old systems, after controlling for other factors that might influence these decisions.

Using the three surveys, we build an unbalanced panel of 3,628 men and 2,534 women who were born between 1931 and 1956 and whose retrospective data reflect their 
working status between ages 50 and 70. Each individual enters into our sample as an observation for each year in which he or she falls into our target age group. Because the retrospective questionnaire covers the period 1980-2006, individuals born in 1956 (who were 50 in 2006) contribute with one year to the panel, while those born in 1931 (who were 49 in 1980) contribute with 21 years. Most individuals (92\% of men and $77 \%$ of women) are affiliated to a pension system and of these, $60 \%$ of men and $48 \%$ of women are new system affiliates (see Tables A1 and 1). We link these data to variables that measure macroeconomic conditions for each year of the survey.

We include in our sample all affiliates who were non-pensioners and all recipients of old age and survivors' pensions but we do not include recipients of other types of pensions such as disability or PASIS pensions, because they were subject to differing and complex incentives and selection. We drop non-pensioners at the point when they began to receive these other pension-types. We exclude individuals who were not affiliated to any system - a larger group for women than for men. Thus, we are focusing on the impact of system rules on those who were subject to these rules and had some attachment to the formal labor market at some point in their lives. This gives us observations of 3,267 men and 2,438 women for an average of ten years each, comprising 34,070 menyears and 24,978 women-years.

Of course, old system members come disproportionately from earlier cohorts and are observed disproportionately at older ages than new-system members. Nevertheless, there is substantial overlap in ages and cohorts observed in the old and new systems (Table A1). Unadjusted work probabilities are significantly higher in the new system compared to the old system, for both genders (Figure 1A and 1B). In the next section we 
add controls for age and other individual and time-specific co-variates that might affect these outcomes.

Given the age composition of our sample and the years of observation, all of the old system affiliates in 2006 started out in the old system while the majority of new system affiliates started out in the old system and switched to the new system in 1981-82. To the extent that affiliation is not a random assignment we must pay attention to the possibility of system choice being correlated with other variables that affect labor force participation. In a later section we test for the presence of selection bias. For this part of the analysis, we build an augmented sample that includes cohorts with little or no choice-older cohorts born between 1921 and 1930, most of whom had to be in the old system, and younger cohorts born between 1957 and 1966, most of whom had to be in the new system.

\section{Probit model of retirement and pension probabilities}

We use probit analysis to estimate retirement probabilities for older individuals. Our main dependent variable is the individual's labor force participation rate $\left(\mathrm{LFP}_{\mathrm{i}}\right)$, which we model as a function of the individual's affiliation with the new or old systems $\left(\mathrm{S}_{\mathrm{i}}\right)$, controlling for personal and family characteristics $\left(\mathrm{X}_{\mathrm{i}}\right)$, pension status $\left(\mathrm{P}_{\mathrm{i}}\right)$ and timespecific macro-economic conditions as represented by unemployment rate $\left(\mathrm{UnE}_{\mathrm{t}}\right)$ —all variables that influence the person's potential wage and willingness to trade-off wage for leisure. In our reduced form probit model:

$$
\operatorname{Pr}\left(L F P_{i}=1 \mid S_{i}, X_{i}, P_{i}, U n E_{t}\right)=\Phi\left(S_{i} \delta_{L}+X_{i} \beta_{L}+P_{i} \lambda+U n E_{t} \gamma_{L}\right)
$$

where $\Phi$ is the standard cumulative normal probability distribution and $S_{i} \delta_{L}+X_{i} \beta_{L}+P_{i} \lambda$

$+U n E_{t} \gamma_{L}$ is the probit score for the LFP probit model. The model estimates a set of parameters that measure the effect of covariates on the probit score, and thus on the 
probability of LFP. We are particularly interested in $\delta_{L}$, which measures the effect of the pension reform on labor force participation. We also display these probabilities separately for these pensioners and non-pensioners, given the possibility that these two groups will behave differently. We include pension amount $\left(B_{i}\right)$ and time since pensioning $\left(T P_{i}\right)$ as additional variables for pensioners.

As a subsidiary point, to see whether pensioning has been postponed by the reform, we also estimate the probability of being a pensioner:

$$
\operatorname{Pr}\left(P E N_{i}=1 \mid S_{i}, X_{i,} U n E,\right)=\Phi\left(S_{i} \delta_{p}+X_{i} \beta_{p}+U n E_{t} \gamma_{p}\right)
$$

where $R_{c} \delta_{P}+X_{i} \beta_{P}+U n E_{t} \gamma_{P}$ is the probit score for the PEN model.

There is a basic difference between the LFP and PEN equations. Once a person pensions, he or she stays pensioned; it is a once-and-for-all decision. For reasons given above, we expect that in the new system, as in the old, most individuals will start the pension as soon as possible; but we expect this action to be postponed in the new system because of tighter early retirement and MPG eligibility rules.

In contrast, the LFP decision is remade each month or year, since people can and do move in and out of employment. This paper models the LFP decision in each year as separable from previous years and pension status and amount as given by previous decisions which are immutable once the individual becomes a pensioner. ${ }^{12}$

\section{Variables used in the panel analysis}

In our panel analysis we explain pension probabilities and participation rates of older individuals as a function of system affiliation, individual-specific time-invariant covariates (gender, education as a proxy for potential earnings and pension, birth cohort), individual-specific variables that vary over time (age, pensioner status and amount, years since pension began, marital status) and macro-economic time effects (unemployment 
rate). ${ }^{13}$ (See Table 1 for list of sample characteristics). We focus on the new-system effect and the variables that are hypothesized to influence its magnitude-pension status, gender, education and age. Hypotheses and findings about the other variables are discussed in the Appendix. Since the higher work incentives facing new system members vary depending on whether they are men or women, pensioners or non-pensioners, high or low earners, we calculate the marginal impact of the new system separately by gender, pensioner status and level of education.

System affiliation $\left(S_{i}\right)$. Reform indicators are the main variables in our empirical analysis. In a previous paper we used the individual's birth cohort as an indicator of the probability that he was in the new system (Edwards and James 2008). In this case, we know the system affiliation directly. Individuals who were in the old system in 2006 were, by definition, in the old system for all of their working lives. Individuals who were in the new system in 2006 were in the new system for their entire working lives if they entered the labor force after the reform. If they entered before the reform they were in the old system initially, then switched. The data do not give us the switching year, but we know that most switching occurred between 1981-83. We assign them to the old system until 1982, the new system thereafter (see discussion of the switching decision and selection bias below).

Pension status $\left(P_{i}\right)$. In the labor force participation analysis, we include specifications with and without pensioner status as a co-variate. Non-pensioners are more likely to work than pensioners because of liquidity constraints--they do not yet have access to their pension wealth for consumption. Therefore, tighter early retirement rules that increase the proportion of non-pensioners should increase the probability of work, in specifications that do not control for pension status. In specifications that do control for 
pensioner status, we expect this to have a negative direct impact on work propensities in both systems. But the new system should have a particularly strong positive impact on the labor force participation of pensioners, because of the removal of work restrictions and their exemption from the pension payroll tax. The pensioner-non-pensioner LFP gap should fall. We also investigate the possibility that selection into pensioner status may vary across systems and influence these results.

Education. Education is represented by a dummy for persons who acquired at a complete secondary education or more. ${ }^{14}$ It is a proxy for permanent earning capacity. On the one hand, higher education exerts a lifetime income or wealth effect that might lead to earlier withdrawal from the labor force; but on the other hand it also has a positive substitution effect on work propensities, by raising the pecuniary reward for work and giving access to more interesting jobs. The net impact of education on participation rates of older workers is therefore uncertain a priori.

More important for our purposes, we expect that the marginal impact of the new system on pension probabilities and participation rates will vary for people with and without secondary education. Those without secondary education are less likely to satisfy the new pension eligibility conditions which would allow them to stop work early with a pension, while they could do so more easily in the old system. This would lead to a more negative reform effect on pension probabilities and a more positive reform effect on participation rates for less educated workers. The tighter 20 -year requirement for the MPG may strengthen this interaction of reform effect with education.

Gender. Men and women may react differently to the new system because of their different life circumstances. Older women have worked less in their younger ages than older men, and earned lower wages. They had less education, because of the gender 
differences in schooling until the last two decades, and this in turn lead to lower labor force participation, wages and pension accumulations. We include in this study only those who are affiliated to a social security system, which means they have worked in the market to some extent--but less than men. Therefore, they are less likely to be able to pension early in the new system; the tighter restrictions are more binding for them. Also, they are more likely to be candidates for the MPG, and consequently have a further incentive to postpone pensioning and withdrawal from the labor market until they achieve eligibility. For both these reasons, we expect a stronger reform impact on women, regardless of educational levels.

In both systems, marriage may have a positive direct impact on men's participation rates because they wish to support a spouse and children, and a negative direct impact on women's participation, because they have a spouse to support them. However, the treatment of survivors' benefits may increase the positive new-system effect for women, especially married women and widows. In the old system, wives had to give up their own pension to get the survivor's benefit. Their contributions then became a pure tax. In the new system this tax is removed as women are permitted to keep their own pension in addition to the survivor's benefit. In contrast, men had to forego part of their own-pension in order to purchase a joint pension that covered their wives, upon retirement. This is another reason why we would expect a larger new-system effect on participation rates for women than for men.

This would hold for widows and also for married women who are not yet widowed but anticipate they may be some day. However, to the extent that people are myopic and respond more strongly to immediate incentives, women receiving survivors' benefits will exhibit a particularly high new-system effect. They are relieved of two taxes 
on their labor--the pension payroll tax and the crowd-out by the survivor's benefit of their own-pension. Therefore, the marginal new-system effect may be more positive for women on survivors' benefits than for other women or for men on old age benefits.

Age. Since pension probability increases and participation decreases with age and the new and old systems had different age distributions, it is important to control for age. In our probits we treat age as a continuous variable and we also introduce a dummy for women who are over age 60 and men who are over 65 . In addition, age affects the marginal new-system effect, since the rules vary by age. At 60 for women, 65 for men, all workers can start their pension, regardless of accumulation size. Therefore, the newsystem constraints on early pensioning should end at that point.

\section{Results: Impact of Reform on Pension and Participation Probabilities}

Tables A1 and A2 present our probit estimates and the Appendix also discusses the co-variates that determine pension and work probabilities. In the text we concentrate on the new-system impact on these probabilities. Tables 2 and 3 show the marginal impact of the new system on pension and participation for various groups-over-all and broken down by gender, pension status and education levels.

\section{Reform impact on pension probabilities}

As expected, we find that individuals affiliated to the new system postpone pensioning (Table 2). Pension probabilities for men in their 50's fall by about 14 percentage points, which is almost half of the old-system average pension probability of $29 \%$. These numbers seem very large, but they are consistent with the raw data showing decreased pension probabilities for older age groups over the period 1981-2004 and with our previous analysis of postponed pension probabilities for post-reform male cohorts (Figure 2 and Edwards and James, 2008). The decline comes to an end at age 65, as 
expected. The absolute value of the change is slightly larger for men with secondary education, but the value relative to initial pension probabilities is much larger for men without secondary schooling, also as expected.

For women, pension postponement in their 50's was smaller (about 6 percentage points) but still highly significant and somewhat more concentrated on those with secondary education. This somewhat surprising result may be due to the limited labor market attachment of women - many were probably constrained by the early pension requirements in the old system, so the new-system constraints were redundant. Those with secondary education were more likely to meet the old-system conditions for early retirement but to be constrained by the more stringent new-system requirements.

Postponed pensioning could be caused by tighter early retirement constraints or by voluntary choice under greater actuarial fairness, which made workers more willing to save through the pension system. We cannot directly separate these two sources for women under 60 or men under 65 . However, since everyone is eligible to start their pension by $60 / 65$, postponement beyond those ages is voluntary and would be evidence that marginal actuarial fairness has had an impact. In fact, over ages 60/65, our estimations show that pension postponement comes to an end - that is, individuals eventually get a pension, but they start it later in old age. Thus, tighter constraints on early retirement seem to be the dominant reason for postponed pensioning.

Since the difference in labor force participation rates of male pensioners and nonpensioners is about 30 percentages points, a 14 percentage point shift of men from pensioner to non-pensioner status should increase the average participation rates of men in their 50's by about 4 percentage points and of older men over-all by about 3 percentage points. For older women, the smaller shift from pensioner to non-pensioner 
status, combined with a smaller pensioner-non-pensioner participation differential, produces a 1 percentage point increase in their average labor force participation rates.

\section{Reform impact on labor market participation rates}

The reform impact on labor force participation rates is even more striking. In Table 3, col. 2, without pension controls, we capture all sources of increased participation among pensioners and non-pensioners. Participation rates of the average man goes up 10 percentage points, compared with an initial participation rate of $65 \%$--a $15 \%$ increase. Controls for pension status (Table 3, col. 3) indicate that this increase is mainly due to the higher rate among pensioners. Participation rates among pensioners go up by 9 percentage points, which is $21 \%$ of their old-system rate. Participation of non-pensioners also goes up significantly but only by 6 percentage points, which is $8 \%$ of their oldsystem rate. This is consistent with our hypothesis that the exemption from the payroll tax (experienced by pensioners) is a more powerful motivator than actuarial fairness (experienced by non-pensioners). It is also consistent with the raw data, which show strongly increased participation rates of older men, especially pensioners, over the period 1981-2004 and with our previous analysis of rising participation rates for post-reform male cohorts (Figure 3 and Edwards and James, 2008).

Also playing an important role is the shift of individuals into non-pensioner status, as pension age is postponed. The average new-system effect goes down by 3.3 percentage points (10.1 in col. 2-6.8 in col. 3) when we control for pension status. This suggests that $32 \%(3.2 / 10.1)$ of the over-all new-system effect on male participation rates is due to the increased proportion of non-pensioners, who work more than pensioners. (The impact of this increased proportion is eliminated once pension status is controlled, 
in col. 3). This is consistent with our estimate above of a 3 percentage point impact of postponed pensioning on participation rates of older men.

Among women, participation rates go up 20 percentage points, compared with a $36 \%$ participation rate in the old system - a dramatic 55\% increase. In absolute value, marginal effects are very similar for pensioners and non-pensioners, but relative to oldsystem values they are again much higher for pensioners. Most striking is the huge relative new-system effect for women recipients of survivor benefits - their participation rates rise by $140 \%$ relative to old-system rates. This is consistent with the fact that the new system exempted survivor beneficiaries from the pension payroll tax and from the tax on their own-pension. Knowing that they could still keep their own pension in the future may also help account for the high new-system impact on participation rates of older women more broadly, even before they become recipients of survivors' benefits. Below we discuss whether selection and maturation may be contributing to these results, especially the high rates among women.

Both for men and women, increases in participation rates relative to rates for oldsystem members are larger for individuals without secondary education. As suggested above, it is possible that these low earners continue working late in life, both as pensioners and non-pensioners, to become eligible for the MPG.

\section{Could the larger reform effect on pensioners be due to selection bias?}

The evidence points toward a stronger reform impact on pensioners, as we hypothesized. The weaker response among non-pensioners may be due to the fact that the system remains actuarially unfair to them (albeit less so than previously) because their time and investment preferences are different from those imposed by the system. In addition, their gains from longer work are less clear-but, while the total elimination of the 
pension payroll tax is easy for pensioners to see. Moreover, non-pensioners are already working at very high rates so there is not much space for further increases.

Could the larger response by pensioners be due to selection bias - a change in composition among pensioners toward those with higher work propensities and vice versa for non-pensioners? Under the old system, some individuals with a high propensity to work had to postpone pensioning in order to keep their job. The delinking of work and pension choices in the new system means that these individuals can now become pensioners and continue to work. At the same time, the tightening of early retirement restrictions means that fewer people can satisfy the pre-conditions for pensioning prior to age 65. The new system conditions early access to pension on meeting a fund accumulation/replacement rate threshold, which is more likely to be achieved by those who contributed persistently-because they have higher work propensities. The old system granted early retirement status more liberally, and possibly to many with lower work propensities. All these effects could raise average participation rates among newsystem pensioners compared with old-system pensioners, due to selection bias into pensioner status of those with high work propensities.

However, our findings are not consistent with selection as the major explanation. If the shift of individuals with high work propensities into pensioner status were the main reason for the higher work proclivities of new-system pensioners, it follows that labor force participation would have fallen for non-pensioners in the new system and would not have risen over-all, in specifications where pension status was not controlled. On the contrary, we find that non-pensioners remain more likely to work than they did before the reform and the increase in participation rates remains (in fact, is larger) when pension status is not controlled. This growth in over-all work propensities is consistent with the 
view that we are observing behavioral change due to new incentives and constraints, rather than simply a rearrangement of people with unchanged behaviors.

\section{Testing for selection bias into the new system: choice versus low-choice groups}

The biggest challenge to these results is the possibility of selection bias into the new system. Workers newly entering the labor market after 1981 had to enter the new system, but those already working and affiliated to the old system had choice. Most of the individuals in our sample were in this choice group. Thus, it is possible that selection bias is present in our analysis_-individuals with a higher propensity to work may have been more likely to switch, so we may be observing the switching decision rather than participation change.

Age in 1981 turns out to be a primary factor influencing the switching decision (see Palacios and Whitehouse 1998); younger workers were more likely to switch than older workers, because they had more years ahead of them in which to compound interest in their accounts in the new DC system. Our sample consists of older workers and we control for age differences within this group. But holding age constant, those who expected to work longer in the future were more likely to switch than those with a more tenuous work attachment, because their contributions would build their accounts in the DC system but would yield little or no returns in the old system after 30 years. This would lead to a selection into the new system of people who expected to have higher

participation rates in old age. ${ }^{15}$ For our analysis, the important point is that unobserved expectations about future participation rates may have influenced the switching decision (although many other factors were also at work), so part of our new system effect may be due to selection rather than changed behavior. 
We carried out several tests to investigate this possibility, augmenting our sample to include groups who had little or no choice and comparing the behavior of these groups with our main sample, most of whom had full choice. The positive new-system effect on behavior remains strong, even when the no-choice or low-choice groups are added.

We start by augmenting our main sample with 2 sub-groups: 1) those who were born 1957-66, who were 15-24 in 1981; many of them entered the labor market after 1981 so had no choice - they had to enter the new system; and 2) those who were born 1921-30, who were 51-60 in 1981; they were unlikely to choose the new system even if they had high expected participation rates, because they had few years ahead of them in which to build their accounts before retirement. Both these groups are relatively free of selection bias. We compare participation rates within each system by cohort and across systems with the augmented versus the main sample. If selection bias exists, participation rates should differ between the choice and low-choice cohorts and the new-system effect will be smaller when the low-choice groups are included in the regression.

This augmented sample, however, poses some problems. For example, the lowchoice group in the new system is observed only in a limited age range - 40-49—which is outside the older workers age 50-70 on which we are focusing. In contrast, the lowchoice group in the old system is observed only over 50. This absence of overlap in birth years and observed ages means that we can't simply compare the behavior of the two low-choice groups. Moreover, the earlier cohorts will make the augmented old system sample more subject to deaths, survivor bias and other time-specific forces than is the main sample (see James, Edwards and Iglesias 2009 for fuller explication of this point). Indeed, these are the reasons why we didn't confine our entire analysis to the low-choice groups. 
We proceed with hypotheses about the impact of selection bias. If workers with high expected participation rates have selected into the new system, then:

1. Within the new system, participation rates should be lower for the low-choice cohorts born 1957-66 than for earlier cohorts whose members voluntarily switched to the new system. As noted above, the cohort born 1957-66 is represented only in ages 40-49 in our sample. Therefore, to test this hypothesis we regress labor force participation rate on the usual co-variates, for age group 40-49 only, with cohort dummies for cohorts born 1931-40, 1951-56 and 1957-66 (cohorts born 1941-50 are omitted)-for the new system only. As in our previous regressions, we control for age, education, marital status, and unemployment rate. A negative coefficient on cohort 1957-66 would be consistent with selection bias. Although the sign turns out to be negative, it is not significant either for men or women (Tables 4 and 5, Panel A, col. 1).

2. Comparing across systems, the new system effect on participation should fall when the low choice cohort born 1957-66 is included in the sample. To test this hypothesis, we regress labor force participation rate on the usual co-variates, including the new system dummy-for new versus old system members. Since the augmented cohorts are only present for ages $40-49$, to capture them we must expand our age range to ages 40-70. Even in the absence of selection bias the new system effect is likely to be smaller for this expanded age range, since most prime-age men work in both systems. Therefore, to isolate the effect of the added low-choice cohorts, we re-estimate the main sample (cohorts 1931-56) for the expanded age range and compare with the system coefficient for the augmented sample (cohorts 1931-66). If the new-system effect is smaller in the augmented sample, this is consistent with selection bias. In fact, the new- 
system coefficients are not significantly different between the augmented and main samples for either gender (Tables 4 and 5, Panel A, col. 2 versus 3).

3. Within the old system, participation rates should be higher for the low-choice group born 1921-30 than for later cohorts whose members had more opportunity to switch. To test this hypothesis we regress labor force participation rates on the usual covariates in age group 50-70, with cohort dummies for cohorts born 1921-30, 1931-40 and 1951-56 (cohorts born 1941-50 are omitted)_for the old system only. A positive coefficient on cohort 1921-30 would be consistent with selection bias. In fact, the coefficient is not statistically significant for women and it is significantly negative for men (Tables 4 and 5, Panel B, col. 1).

4. Comparing across systems, the new system effect on participation should fall when the low choice cohort born 1921-30 is included. To test this hypothesis, we regress labor force participation rates on the usual co-variates, including the new system dummy-for age group 50-70, for new versus old system members. A smaller new system effect in the augmented sample would be consistent with selection bias. We found no significant difference between the augmented and main samples for either gender (Tables 4 and 5, Panel B, col. 2 versus 3).

5. The new system effect on participation should fall when both low choice cohorts, born 1921-30 and 1957-66 are included. Finally, we ran our regressions with the fully augmented sample for ages 40-70, for new versus old system members. A smaller new system effect in the augmented sample, as compared with the main sample for these ages, would be consistent with selection bias. Again, there was no significant difference for either gender (Table 4, Panel A, col. 3 versus 4). 
Thus, the addition of groups for which there is little or no choice of system has no impact on the new-system effect. Labor force participation rates increase by about 10 percentage points in all cases for men, which is about $15 \%$ of the old-system participation rate. It increases by about 20 percentage points for women, which is $55 \%$ of the oldsystem rate. In addition, as discussed in the next section, the average labor force participation rate for both systems combined has increased over time, as the proportion of new-system affiliates has grown. This shows that behavioral change, and not merely a rearrangement of people with unchanged work propensities, is involved. (for corroborating evidence based on cohort analysis, see Edwards and James 2008).

\section{Maturation bias}

In our efforts to measure the impact of system rules on individual behavior, we restrict our analysis to individuals affiliated to the new or old system. The "new-system effect" depicts the increased probability of working for an otherwise identical person who happens to be affiliated to the new rather than the old system. That is, "affiliates" are taken as a proxy for potential workers and eventual pension recipients in that system. A problem occurs because the relationship between current workers and affiliates is different for new and old systems. Only workers can join the new system, and all new entrants to the labor force must also join. In contrast, the old system has members who worked in the past, then retired, became informal or withdrew from the labor force; they are not potential workers now. This is a special case of selection, in which the selection occurs not by worker choice but because of the way system affiliation is assigned or defined. Consequently, the ratio of workers/affiliates will fall dramatically as the system matures, simply because "affiliates" rises faster than "workers", by definition. 
Comparisons of work probabilities among affiliates are biased in favor of immature new systems, due to this "system maturation effect."

This problem is especially great for women. Many older women entered the labor force for the first time in the 1980's and 1990's, after their child-rearing years, because of changing social norms and economic growth during this period. These women all had to enter the new system. Then, the extremely high apparent new-system effect for women may be due, in part, to the forced selection of this large group into the new system.

If the new system effect were simply due to maturation bias, it would disappear over time, as the proportion of affiliates who were not potential workers was equalized for the two systems. Also, if we regressed the probability of work over the two systems combined in a given year, as a function of the share of new-system affiliation, the latter should be insignificant if only system maturation was at work, but it should have a significant positive coefficient if real behavioral change in the new system was involved. We carried out this exercise (including age and education as co-variates) and found that the average participation rate goes up significantly, by .2 percentage points for men, .1 percentage points for women, for every percentage point increase in the proportion of total affiliates who are in the new system (Table 6). ${ }^{16}$

In sum, some maturation bias is undoubtedly present, especially for women, but this does not tell the whole story-the growing membership in the new system increases aggregate participation rates. This regression is also another indication that selection of system by workers who had a choice is not the full explanation. The individual-level regressions by system show higher participation probabilities for affiliates of the new system, because of the incentives and constraints that they face, and the regressions of participation probabilities by year combining both systems show that as 
the new system is phased in, labor supply rises for the economy as a whole; we are not simply observing biases caused by system selection or maturation.

\section{Conclusion}

Many countries with aging populations are seeking ways to increase work propensities and delay pension probabilities of their older workers. Chile is an unusual case in that the labor force participation rates of its older workers have been increasing and pension probabilities decreasing for the past 25 years. We argue that this is mainly due to incentives and constraints stemming from its new social security system.

Pre-reform Chile looked like many European countries today-with early and declining age of pension and withdrawal from the labor force. These incentives, constraints and trends were sharply reversed in 1981, when a new pension system with pro-work incentives and constraints was adopted. We hypothesize that participation rates of older workers will increase due to: 1) Greater incentives for pensioners to continue working because the new system eliminates restrictions that existed previously and exempts pensioners from the pension payroll tax; 2) Greater actuarial fairness, which may lead to postponed pensioning and higher participation rates of non-pensioners on a voluntary basis because of the smaller implicit tax; 3) Tighter early pension preconditions, which constrain more individuals to remain non-pensioners and to continue working because of liquidity constraints; 4) Tighter eligibility conditions for the MPG, which induce low earners to work longer; and (5) new treatment of survivors' benefits, which allowed recipients to also keep their own-benefit and thereby induce widows and women more broadly to work longer.

We use probit analysis of data of a retrospective sample of new and old system affiliates to test these hypotheses about pension probabilities and labor force participation 
rates in the new versus the old systems. Our results are consistent with these hypotheses. We estimate an increase of 10 percentage points or $15 \%$ in the participation rates of older men, and 20 percentage points or $55 \%$ in participation rates of older women, who are new-system members. Pensioners experience the largest impact; the effect on nonpensioners is also significant, but much smaller. This suggests that the removal of work restrictions and exemption from the pension payroll tax is a more potent incentive than the move toward actuarial fairness. Actuarial fairness is difficult concept for workers to understand and calculate. In addition, the new system remains only partially fair given that it imposes higher savings rates than would be voluntarily chosen by workers. Another large part of the total new-system effect stems from tighter early retirement restrictions that constrain individuals to postpone pensioning and continue working. Particularly noteworthy is the huge (140\%) increase in work propensities by new-system recipients of survivors' benefits, as the $100 \%$ implicit tax that many of them previously faced on own-pension has now been eliminated.

Although individual characteristics and macro-economic cycles have significant impacts on participation rates, they do not erase these reform effects. Moreover, the changes we find are inconsistent with an explanation based on selection or maturation, since they produce an over-all increase in labor force participation rather than simply a rearrangement between groups.

These results have important policy implications. They suggest that, regardless of other features of the system, the labor supply of older individuals can be increased substantially by 1) raising the reward that older individuals receive for working, for example by exempting them from the pension payroll tax; 2) raising the earliest allowable age for pensioning or doing so automatically and gradually by tying pension 
age to life expectancy; and 3) financing survivors' benefits in a way that makes it feasible for women who have worked and contributed to keep their own-pensions as well. ${ }^{17}$ Countries that wish to retain older individuals in the labor force might consider adopting these policies. 


\section{Appendix: Hypotheses and results re other co-variates}

We include many other co-variates in our probits, to control for their direct effect on pension probabilities and participation rates.

Benefit amounts. The pension system may also exert an influence on participation via its impact on monthly pension payouts and social security wealth. During the period covered by this study, 1980-2006, inflation-adjusted pensions were rising, in Chile. In addition, at any point in time pension amounts varied by individual, depending on their work histories and education. The pension amount was determined by a formula in the old DB system, and by an actuarial conversation to an annuity or programmed withdrawal pension in the new DC system. Annuities have a constant real value while programmed withdrawals vary depending on rates of return and duration. For this study, we use the real value in 2006 in the regressions for the pensioner sub-sample. A higher benefit may lead pensioners to withdraw from the labor market via a wealth or income effect. But it may also signal that the individual has a higher potential wage, which may induce him or her to continue working, via the substitution effect. We are not sure a priori which effect will dominate. It turns out that pension amount has a negative impact on participation, implying that the wealth or income effect dominates, for men, but pension amount is insignificant for women. ${ }^{18}$

Years since pension began. We expect that, even though the reform introduced incentives that disconnect the pension decision from the work decision, starting the pension remains the first stop toward labor force withdrawal, since it creates an alternative source of income. It signals that the worker is thinking about retiring. While he may postpone that decision, the more time elapses since pensioning the more likely he is to have withdrawn from the labor force and the harder it will be to re-enter. Consistent 
with this expectation, years since pensioning has a significant negative impact on participation rates, but this coefficient is significant only for men.

Unemployment. During the post-reform period covered by this study, unemployment went through an entire cycle. From a high of $23 \%$ in 1982 , it fell to $6 \%$ by 1995 and then rose to $14 \%$ by 2002 . We expect pension probabilities to rise and LFP to fall during cyclical downturns in the economy, due to the discouraged worker effect, the difficulty older workers may experience in obtaining new jobs when laid off from their existing jobs, and the greater ease of meeting early retirement pre-conditions. It turns out that, for men, pension probabilities fell significantly during periods of high unemployment, while for women there is no significant unemployment effect. However, the negative impact of unemployment on participation rates are strongly significant both for men and women.

Cohort. Our observations occurred over a 20-year time span, during which education levels and income per capita rose, an entire business cycle occurred and social norms regarding the role of women changed. Our inclusion of education levels and unemployment rate accounted for some of these changes but not all. To control for other secular trends in participation rates that were unrelated to pension system, we identify each individual by his cohort group (born 1921-30, 1931-40, 1941-50, 1951-56, 1957-66) in all specifications.

Variables added for the 2006 cross-sectional analysis. For some individual-level variables that vary over time, we do not have information for each year but we do have this information for the sample year, 2006. These variables-number of children, spousal work and pension status, knowledge about the system, health status, other savings and household income per capita - will be included in a supplementary cross-sectional 
analysis for 2006 but they were not included in our panel analysis. 
Table 1: Sample Characteristics

\begin{tabular}{|l|r|c|c|c|c|c|}
\hline & \multicolumn{3}{|c|}{ Men } & \multicolumn{3}{c|}{ Women } \\
\hline & Sample & $\begin{array}{c}\text { New } \\
\text { System }\end{array}$ & $\begin{array}{c}\text { Old } \\
\text { System }\end{array}$ & Sample & $\begin{array}{c}\text { New } \\
\text { System }\end{array}$ & $\begin{array}{c}\text { Old } \\
\text { System }\end{array}$ \\
\hline Percentage working & 0.745 & 0.806 & 0.652 & 0.480 & 0.615 & 0.356 \\
\hline Percentage married & 0.746 & 0.759 & 0.727 & 0.581 & 0.553 & 0.607 \\
\hline $\begin{array}{l}\text { Percentage with secondary } \\
\text { school }\end{array}$ & 0.251 & 0.291 & 0.192 & 0.279 & 0.370 & 0.194 \\
\hline orn in 1931-1940 & 0.442 & 0.339 & 0.597 & 0.425 & 0.242 & 0.593 \\
\hline Born in 1941-1950 & 0.429 & 0.478 & 0.356 & 0.433 & 0.522 & 0.351 \\
\hline Born in 1951-1956 & 0.129 & 0.183 & 0.047 & 0.142 & 0.236 & 0.057 \\
\hline Mean Age & 56.77 & 56.04 & 57.857 & 56.7 & 55.4 & 57.9 \\
\hline Percentage Old-Age pensioners & 0.246 & 0.183 & 0.341 & 0.191 & 0.101 & 0.273 \\
\hline Percentage survivors' pensions & na & na & na & 0.060 & 0.063 & 0.057 \\
\hline Percentage in New System & 0.600 & 1.000 & 0.000 & 0.479 & 1 & 0 \\
\hline \# obs & 34,070 & 20,438 & 13,632 & 24,978 & 11,976 & 13,002 \\
\hline
\end{tabular}


Table 2: Probability of Old-Age Pension: Marginal Effect of New System

(Calculated for different values of covariates, affiliates ages 50-70, birth years $1931-56)^{1}$

\begin{tabular}{|c|c|c|c|c|}
\hline & \multirow{2}{*}{$\begin{array}{c}\text { Probability } \\
\text { of Pension- } \\
\text { Old } \\
\text { System }\end{array}$} & \multicolumn{3}{|c|}{ Marginal effect of new system } \\
\hline & & $\begin{array}{c}\text { Age 50- } \\
59\end{array}$ & $\begin{array}{c}\text { Age 60- } \\
64\end{array}$ & Age 65-70 \\
\hline \multicolumn{5}{|c|}{ Men } \\
\hline At sample means $^{2}$ & .291 & $-.138 *$ & $-.076^{*}$ & -.039 \\
\hline $\begin{array}{l}\text { With secondary } \\
\text { school }\end{array}$ & .452 & $-.177 *$ & $-.097 *$ & \\
\hline $\begin{array}{l}\text { Without } \\
\text { secondary school }\end{array}$ & .252 & $-.137^{*}$ & $-.075^{*}$ & \\
\hline \multicolumn{5}{|c|}{ Women } \\
\hline & $\begin{array}{c}\text { Probability } \\
\text { of Pension } \\
\text { Old } \\
\text { System }\end{array}$ & $\begin{array}{c}\text { Age 50- } \\
55\end{array}$ & $\begin{array}{c}\text { Age 56- } \\
59\end{array}$ & \\
\hline At sample means ${ }^{2}$ & .273 & $-0.065^{*}$ & $-0.049^{*}$ & \\
\hline $\begin{array}{l}\text { With secondary } \\
\text { school }\end{array}$ & .359 & $-0.103^{*}$ & $-0.079^{*}$ & \\
\hline $\begin{array}{l}\text { Without } \\
\text { secondary school }\end{array}$ & .252 & $-0.053^{*}$ & $-0.039^{*}$ & \\
\hline
\end{tabular}

${ }^{1}$ Probit coefficients are reported in Table A1. Sample excludes disability and PASIS pensioners and non-affiliates.

2 Marginal effects calculated at the sample means except for Dummy 60/65 that is set at zero for consistency.

* significant at $0.1 \%$ 
Table 3: Probability of Work: Marginal Effect of New System

(Calculated at Different Values of Covariates, affiliates ages 50-70, birth years $1931-56)^{1}$

\begin{tabular}{|c|c|c|c|c|c|}
\hline & & \multicolumn{2}{|c|}{$\begin{array}{c}\text { Marginal Effects-new } \\
\text { system }\end{array}$} & \multirow{2}{*}{\multicolumn{2}{|c|}{$\begin{array}{l}\text { Marginal } \\
\text { Effect as \% of } \\
\text { probability of } \\
\text { work in old } \\
\text { system }^{3}\end{array}$}} \\
\hline & \multirow{2}{*}{$\begin{array}{l}\text { Probability } \\
\text { of work-- } \\
\text { old system } \\
\text { (1) }\end{array}$} & \multirow{2}{*}{$\begin{array}{c}\text { No controls } \\
\text { for } \\
\text { pension status } \\
\text { (2) }\end{array}$} & \multirow{2}{*}{$\begin{array}{l}\text { Controls } \\
\text { for pension } \\
\text { status } \\
\text { (3) }\end{array}$} & & \\
\hline & & & & $(3) /(1)$ & $(2) /(1)$ \\
\hline & \multicolumn{3}{|c|}{ Men } & & \\
\hline At sample means $^{2}$ & .652 & $.101 *$ & $.068 *$ & $10 \%$ & $15 \%$ \\
\hline Non-pensioner & .768 & & $.062 *$ & $8 \%$ & \\
\hline Old age pensioner & .430 & & $.09 *$ & $21 \%$ & \\
\hline $\begin{array}{l}\text { With secondary } \\
\text { school }\end{array}$ & .658 & $.093 *$ & $.057 *$ & $9 \%$ & $14 \%$ \\
\hline Non-pensioner & .800 & & $.049 *$ & $6 \%$ & \\
\hline Old age pensioner & .510 & & $.088 *$ & $17 \%$ & \\
\hline $\begin{array}{l}\text { Without secondary } \\
\text { school }\end{array}$ & .651 & $.103 *$ & $.072 *$ & $11 \%$ & $16 \%$ \\
\hline Non-pensioner & .762 & & $.064 *$ & $8 \%$ & \\
\hline \multirow[t]{2}{*}{ Old Age Pensioner } & .399 & & $.090^{*}$ & $23 \%$ & \\
\hline & \multicolumn{5}{|c|}{ Women } \\
\hline At sample means ${ }^{2}$ & .356 & $0.197^{*}$ & $0.194^{*}$ & $55 \%$ & $55 \%$ \\
\hline Non-pensioner & .414 & & $0.193^{*}$ & $47 \%$ & \\
\hline Survivor pensioner & .121 & & $0.170^{*}$ & $140 \%$ & \\
\hline Old age pensioner $^{3}$ & .264 & & $0.179^{*}$ & $68 \%$ & \\
\hline $\begin{array}{l}\text { With secondary } \\
\text { school }\end{array}$ & .473 & $0.201^{*}$ & $0.184 *$ & $39 \%$ & $42 \%$ \\
\hline Non-pensioner & .594 & & $0.178^{*}$ & $30 \%$ & \\
\hline Survivor pensioner & .167 & & $0.190^{*}$ & $114 \%$ & \\
\hline Old age pensioner ${ }^{3}$ & .297 & & $0.193^{*}$ & $65 \%$ & \\
\hline $\begin{array}{l}\text { Without secondary } \\
\text { school }\end{array}$ & .328 & $0.191^{*}$ & $0.192 *$ & $58 \%$ & $58 \%$ \\
\hline Non-pensioner & .375 & & $0.194^{*}$ & $52 \%$ & \\
\hline Survivor pensioner & .115 & & $0.157^{*}$ & $137 \%$ & \\
\hline Old Age Pensioner ${ }^{3}$ & .253 & & $0.169^{*}$ & $67 \%$ & \\
\hline
\end{tabular}

1 Probit coefficients are reported in Table A2. Sample excludes disability and PASIS pensioners and non-affiliates.

${ }^{2}$ Marginal effects calculated at the sample means of covariates except for Dummy 60/65 that is set at zero for consistency.

3 (3)/(1) gives the proportional increase in participation rates in the new system relative to initial values in the old system, holding pensioner status constant. (2)/(1) gives the proportional new-system effect relative to initial values in the old system, taking into account the increase in number of non-pensioners as pension age is postponed in the new system.

All estimated effects are significant at $0.1 \%$ 
Table 4: Selection Experiments, Probit regressions: Marginal Effects--Men Calculated at Sample Mean for Main Sample vs Expanded Samples ${ }^{1}$

Panel A. Ages 40-70

\begin{tabular}{|c|c|c|c|c|}
\hline \multirow{2}{*}{ Sample } & \multirow{2}{*}{$\begin{array}{c}\text { Affiliates in } \\
\text { New System, } \\
\text { ages 40-49 } \\
\text { Birth Year } \\
1931-67\end{array}$} & \multicolumn{3}{|c|}{$\begin{array}{c}\text { Affiliates in the New and Old Systems, } \\
\text { ages 40-70 }\end{array}$} \\
\hline & & $\begin{array}{l}\text { Birth Year } \\
1931-57\end{array}$ & $\begin{array}{c}\text { Birth Year } \\
\text { 1931-67 }\end{array}$ & $\begin{array}{l}\text { Birth Year } \\
\text { 1921-67 }\end{array}$ \\
\hline & (1) & $(2)$ & (3) & (4) \\
\hline New system & & $0.090^{*}$ & $0.086^{*}$ & $0.095^{*}$ \\
\hline \multicolumn{5}{|l|}{ Covariates } \\
\hline Coh 1921-30 & & & & $-0.056^{*}$ \\
\hline Coh 1931-40 & -0.011 & $-0.036^{* *}$ & $-0.034^{* *}$ & $-0.037^{* *}$ \\
\hline Coh 1951-56 & 0.013 & 0.000 & 0.000 & 0.000 \\
\hline Coh 1957-66 & -0.010 & & $-0.034^{*}$ & $-0.039^{* *}$ \\
\hline Age & $-0.004^{*}$ & $-0.010^{*}$ & $-0.010^{*}$ & $-0.011^{*}$ \\
\hline Dummy Age 65+ & & $-0.103^{*}$ & $-0.099^{*}$ & $-0.120^{*}$ \\
\hline Married & $0.040^{*}$ & $0.173^{*}$ & $0.157^{*}$ & $0.178^{*}$ \\
\hline Secondary degree & $0.105^{*}$ & $0.038^{*}$ & $0.044^{*}$ & $0.047^{*}$ \\
\hline Unemployment Rate & $-0.002^{\mathrm{m}}$ & $-0.006^{*}$ & $-0.006^{*}$ & $-0.005^{*}$ \\
\hline \# observations & 30,932 & 64,773 & 74,395 & 83,349 \\
\hline Probability of work & .918 & .812 & .825 & .792 \\
\hline
\end{tabular}

Panel B. Ages 50-70

\begin{tabular}{|c|c|c|c|c|}
\hline \multirow{2}{*}{ Sample } & \multirow{2}{*}{$\begin{array}{c}\text { Affiliates in } \\
\text { Old System } \\
\text { Birth Year } \\
1921-57\end{array}$} & \multicolumn{3}{|c|}{$\begin{array}{c}\text { Affiliates in New and Old Systems, } \\
\text { Ages 50-70 }\end{array}$} \\
\hline & & $\begin{array}{l}\text { Birth Year } \\
\text { 1921-57 }\end{array}$ & $\begin{array}{l}\text { Birth Year } \\
1931-57\end{array}$ & $\begin{array}{c}\text { Birth Year } \\
1941-57\end{array}$ \\
\hline & (1) & (2) & (3) & (4) \\
\hline New system & & $0.114^{*}$ & $0.102^{*}$ & $0.098^{*}$ \\
\hline \multicolumn{5}{|l|}{ Covariates } \\
\hline Coh 1921-30 & $-0.120^{*}$ & $-0.077^{*}$ & & \\
\hline Coh 1931-40 & $-0.075^{*}$ & $-0.055^{*}$ & $-0.054^{*}$ & \\
\hline Coh 1951-56 & $-0.086^{\mathrm{m}}$ & -0.029 & -0.022 & -0.025 \\
\hline Age & $-0.019^{*}$ & $-0.019^{*}$ & $-0.017^{*}$ & $-0.015^{*}$ \\
\hline Dummy Age 60+ & $-0.112^{*}$ & $-0.098^{*}$ & $-0.068^{*}$ & -0.002 \\
\hline Married & $0.227^{*}$ & $0.183^{*}$ & $0.144^{*}$ & $0.044^{*}$ \\
\hline Secondary degree & 0.004 & $0.045^{*}$ & $0.044^{*}$ & $0.038^{*}$ \\
\hline Unemployment Rate & $-0.006^{*}$ & $-0.007^{*}$ & $-0.012^{*}$ & $-0.008^{*}$ \\
\hline \# observations & 20,866 & 43,024 & 34,070 & 19,004 \\
\hline Probability of work & .599 & .699 & .745 & .817 \\
\hline
\end{tabular}

${ }^{1}$ Sample excludes disability and PASIS pensioners and non-affililates

* significant at $0.1 \%$

** significant at $1 \%$

$\mathrm{m}$ marginally significant at $10 \%$ 
Table 5: Selection Experiments, Probit Regresions: Marginal Effects-Women

Calculated at Sample Mean for Main Sample vs Expanded Samples

Panel A. Ages 40-70

\begin{tabular}{|c|c|c|c|c|}
\hline \multirow[t]{3}{*}{ Sample } & \multirow{2}{*}{$\begin{array}{c}\text { Affiliates in } \\
\text { New System, } \\
\text { Ages 40-49 } \\
\text { Birth Year } \\
\text { 1931-67 }\end{array}$} & \multicolumn{3}{|c|}{$\begin{array}{c}\text { Affiliates in New and Old Systems, } \\
\text { Ages 40-70 }\end{array}$} \\
\hline & & $\begin{array}{c}\text { Birth Year } \\
1931-57\end{array}$ & $\begin{array}{c}\text { Birth Year } \\
\text { 1931-67 }\end{array}$ & $\begin{array}{c}\text { Birth Year } \\
1921-67\end{array}$ \\
\hline & (1) & (2) & (3) & (4) \\
\hline New system & -- & $0.212^{*}$ & $0.209^{*}$ & $0.211^{*}$ \\
\hline \multicolumn{5}{|l|}{ Covariates } \\
\hline Coh 1921-30 & -- & -- & -- & 0.009 \\
\hline Coh 1931-40 & 0.061 & $0.045^{* *}$ & $0.044^{* * *}$ & $0.045^{\mathrm{m}}$ \\
\hline Coh 1951-56 & $-0.056^{* *}$ & $-0.041^{* *}$ & $-0.039^{* *}$ & $-0.041^{* * *}$ \\
\hline Coh 1957-66 & -0.151 & -- & $-0.163^{*}$ & $-0.168^{*}$ \\
\hline Age & 0.001 & $-0.008^{*}$ & $-0.007^{*}$ & $-0.008^{*}$ \\
\hline Dummy Age 60+ & -- & $-0.187^{*}$ & $-0.192^{*}$ & $-0.183^{*}$ \\
\hline Married & $0.178^{*}$ & $-0.098^{*}$ & $-0.110^{*}$ & $-0.117^{*}$ \\
\hline Secondary degree + & $-0.118^{*}$ & $0.175^{*}$ & $0.172^{*}$ & $0.176^{*}$ \\
\hline Unemployment Rate & $-0.008^{*}$ & $-0.004^{*}$ & $-0.004^{*}$ & $-0.003^{* *}$ \\
\hline \# observations & 22,630 & 48,228 & 56,481 & 63,036 \\
\hline \# individuals & 3,214 & 2,667 & 4,379 & 4,787 \\
\hline Probability of work & .680 & .555 & .565 & .531 \\
\hline
\end{tabular}

Panel B. Ages 50-70

\begin{tabular}{|c|c|c|c|c|}
\hline \multirow{2}{*}{ Sample } & \multirow{2}{*}{$\begin{array}{c}\text { Affiliates in } \\
\text { Old System } \\
\text { Birth Year } \\
1921-57 \\
\end{array}$} & \multicolumn{3}{|c|}{$\begin{array}{c}\text { Affiliates in the New and Old Systems } \\
\text { Ages 50-70 }\end{array}$} \\
\hline & & $\begin{array}{l}\text { Birth Year } \\
1921-57\end{array}$ & $\begin{array}{l}\text { Birth Year } \\
\text { 1931-57 }\end{array}$ & $\begin{array}{c}\text { Birth Year } \\
1941-57\end{array}$ \\
\hline & (1) & (2) & (3) & (4) \\
\hline New system & -- & $0.204^{*}$ & $0.202^{*}$ & $0.223^{*}$ \\
\hline \multicolumn{5}{|l|}{ Covariates } \\
\hline Coh 1921-30 & 0.009 & 0.014 & -- & -- \\
\hline Coh 1931-40 & 0.043 & 0.031 & 0.029 & -- \\
\hline Coh 1951-56 & -0.052 & $-0.052^{* *}$ & $-0.045^{* *}$ & $-0.054^{* *}$ \\
\hline Age & $-0.016^{*}$ & $-0.019^{*}$ & $-0.018^{*}$ & $-0.015^{*}$ \\
\hline Dummy Age 60+ & $-0.052^{*}$ & $-0.085^{*}$ & $-0.094^{*}$ & $-0.110^{*}$ \\
\hline Married & $-0.129^{*}$ & $-0.100^{*}$ & $-0.085^{*}$ & $-0.116^{*}$ \\
\hline Secondary degree + & $0.147^{*}$ & $0.176^{*}$ & $0.172^{*}$ & $0.199^{*}$ \\
\hline Unemployment Rate & -0.003 & $-0.004^{* *}$ & $-0.009^{*}$ & -0.001 \\
\hline \# observations & 19,086 & 31,533 & 24,978 & 14,370 \\
\hline \# individuals & 1,423 & 2,846 & 2,438 & 1,863 \\
\hline Probability of work & .325 & .438 & .480 & .544 \\
\hline
\end{tabular}

1 Sample excludes disability and PASIS pensioners and non-affiliates.

* significant at $0.1 \%$

$* *$ significant at $1 \%$

$* * *$ significant at $5 \%$

m marginally significant at $10 \%$ 
Table 6: Testing for Maturation Bias: impact on aggregate participation rates over time of rising proportion of new-system affiliates

\begin{tabular}{|c|c|c|c|c|}
\hline 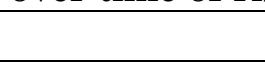 & Coefficient & Standard error & Coefficient & Standard error \\
\hline & \multicolumn{2}{|c|}{ Men } & \multicolumn{2}{|c|}{ Women } \\
\hline constant & $.724 *$ & .015 & $.441^{*}$ & .012 \\
\hline Age & $-.02 *$ & .0007 & $-.021 *$ & .0007 \\
\hline $\begin{array}{l}\text { Secondary } \\
\text { degree }\end{array}$ & $.05 *$ & .007 & $.153 *$ & .008 \\
\hline $\begin{array}{l}\text { New system } \\
\text { affiliates/total } \\
\text { affiliates }^{1}\end{array}$ & $.197 *$ & .021 & $.097 *$ & .019 \\
\hline
\end{tabular}

${ }^{1}$ controlling for year, gender, age and secondary degree

* significant at $0.1 \%$ 
Table A1: Observations by Age and Cohort-Men and Women

\begin{tabular}{|c|c|c|c|c|c|c|c|c|}
\hline \multicolumn{5}{|c|}{ Men } & \multicolumn{4}{|c|}{ Women } \\
\hline & \multicolumn{3}{|c|}{ Year of Birth } & \multirow[b]{2}{*}{ Total } & \multicolumn{3}{|c|}{ Year of Birth } & \multirow[b]{2}{*}{ Total } \\
\hline age & $\begin{array}{c}1931- \\
40\end{array}$ & $\begin{array}{c}\text { 1941- } \\
50\end{array}$ & $\begin{array}{c}1951- \\
56\end{array}$ & & $\begin{array}{c}1931- \\
40\end{array}$ & $\begin{array}{c}1941- \\
50 \\
\end{array}$ & $\begin{array}{c}1951- \\
56 \\
\end{array}$ & \\
\hline 50 & 834 & 1,273 & 1,130 & 3,237 & 569 & 927 & 922 & 2,418 \\
\hline 51 & 832 & 1,263 & 932 & 3,027 & 568 & 925 & 747 & 2,240 \\
\hline 52 & 828 & 1,248 & 767 & 2,843 & 567 & 920 & 615 & 2,102 \\
\hline 53 & 821 & 1,238 & 579 & 2,638 & 565 & 916 & 482 & 1,963 \\
\hline 54 & 817 & 1,218 & 453 & 2,488 & 563 & 904 & 370 & 1,837 \\
\hline 55 & 807 & 1,198 & 307 & 2,312 & 558 & 890 & 237 & 1,685 \\
\hline 56 & 803 & 1,173 & 173 & 2,149 & 553 & 878 & 147 & 1,578 \\
\hline 57 & 789 & 1,141 & 42 & 1,972 & 550 & 853 & 39 & 1,442 \\
\hline 58 & 779 & 1,038 & & 1,817 & 543 & 775 & & 1,318 \\
\hline 59 & 773 & 889 & & 1,662 & 536 & 663 & & 1,199 \\
\hline 60 & 752 & 746 & & 1,498 & 530 & 554 & & 1,084 \\
\hline 61 & 743 & 625 & & 1,368 & 521 & 457 & & 978 \\
\hline 62 & 733 & 529 & & 1,262 & 518 & 387 & & 905 \\
\hline 63 & 720 & 407 & & 1,127 & 516 & 300 & & 816 \\
\hline 64 & 698 & 296 & & 994 & 505 & 213 & & 718 \\
\hline 65 & 680 & 208 & & 888 & 486 & 144 & & 630 \\
\hline 66 & 652 & 103 & & 755 & 471 & 84 & & 555 \\
\hline 67 & 617 & 28 & & 645 & 452 & 21 & & 473 \\
\hline 68 & 545 & & & 545 & 406 & & & 406 \\
\hline 69 & 457 & & & 457 & 342 & & & 342 \\
\hline 70 & 386 & & & 386 & 289 & & & 289 \\
\hline Total & 15,066 & 14,621 & 4,383 & 34,070 & 10,608 & 10,811 & 3,559 & 24,978 \\
\hline $\begin{array}{l}\text { \%new } \\
\text { system }\end{array}$ & 0.460 & 0.668 & 0.853 & 0.600 & 0.273 & 0.578 & 0.793 & 0.479 \\
\hline
\end{tabular}


Table A2: Probit Regression for Probability of Pension ${ }^{1}$

\begin{tabular}{|c|c|c|c|c|}
\hline \multirow[t]{3}{*}{ Sample } & \multicolumn{4}{|c|}{$\begin{array}{c}\text { New and Old System Affiliates } \\
\text { Ages 50-70 } \\
\text { Birth Year 1931-56 } \\
\end{array}$} \\
\hline & Coefficient & $\begin{array}{l}\text { Standard } \\
\text { error }\end{array}$ & Coefficient & $\begin{array}{c}\text { Standard } \\
\text { error }\end{array}$ \\
\hline & \multicolumn{2}{|c|}{ Men } & \multicolumn{2}{|c|}{ Women } \\
\hline Covariates & & & & \\
\hline Constant & $-6.284^{*}$ & 0.245 & $-5.763^{*}$ & 0.293 \\
\hline Coh 1931-40 & $-0.118^{* *}$ & 0.058 & $0.129^{\mathrm{m}}$ & 0.072 \\
\hline Coh 1951-56 & $-0.142^{* * * *}$ & 0.083 & 0.070 & 0.121 \\
\hline Age & $0.093^{*}$ & 0.004 & $0.076^{*}$ & 0.005 \\
\hline Dummy Age 60+ & & & $0.721^{*}$ & 0.060 \\
\hline Dummy Age 65+ & $0.523^{*}$ & 0.058 & & \\
\hline Married & $0.301^{*}$ & 0.061 & $-0.137^{* * *}$ & 0.067 \\
\hline $\begin{array}{l}\text { Secondary degree or } \\
\text { more }\end{array}$ & $0.277^{*}$ & 0.060 & $0.490^{*}$ & 0.076 \\
\hline Unemployment Rate & $0.018^{* *}$ & 0.006 & 0.012 & 0.009 \\
\hline New System*Age50-55 & $-0.620^{*}$ & 0.064 & $-0.496^{*}$ & 0.103 \\
\hline New System*Age56-64 & $0.334^{*}$ & 0.058 & & \\
\hline New System*Age56-59 & & & $-0.407^{*}$ & 0.090 \\
\hline \# of observations & 34,070 & & 24,978 & \\
\hline \# individuals & 3,267 & & 2,438 & \\
\hline Log likelihood & -14327.127 & & -8403.7827 & \\
\hline
\end{tabular}

${ }^{1}$ Sample excludes disability and PASIS pensioners and non-affiliates.

Standard Error adjusted for 2438 clusters

* significant at $0.1 \%$

$* *$ significant at $1 \%$

$* * *$ significant at $5 \%$

$\mathrm{m}$ marginally significant at $10 \%$ 
Table A3: Probit Regressions for the Probability of Work ${ }^{1}$

\begin{tabular}{|c|c|c|c|c|}
\hline \multirow[t]{2}{*}{ Sample } & \multicolumn{4}{|c|}{$\begin{array}{l}\text { New and Old System Affiliates, Ages 50-70 } \\
\text { Birth Year 1931-56 }\end{array}$} \\
\hline & $\begin{array}{l}\text { No pension } \\
\text { controls }\end{array}$ & $\begin{array}{l}\text { Pension } \\
\text { controls }\end{array}$ & $\begin{array}{l}\text { No pension } \\
\text { controls }\end{array}$ & $\begin{array}{l}\text { Pension } \\
\text { controls }\end{array}$ \\
\hline & \multicolumn{2}{|c|}{ Men } & \multicolumn{2}{|c|}{ Women } \\
\hline New System & $0.328^{*}$ & $0.226^{*}$ & $0.512^{*}$ & $0.491^{*}$ \\
\hline \multicolumn{5}{|l|}{ Covariates } \\
\hline Constant & $3.802^{*}$ & $2.453^{*}$ & $2.453^{*}$ & $2.006^{*}$ \\
\hline Coh 1931-40 & $-0.177^{*}$ & $-0.224^{*}$ & 0.072 & 0.066 \\
\hline Coh 1951-56 & -0.070 & $-0.107^{\mathrm{m}}$ & $-0.114^{* *}$ & $-0.100^{\mathrm{m}}$ \\
\hline Age & $-0.056^{*}$ & $-0.030^{*}$ & $-0.044^{*}$ & $-0.036^{*}$ \\
\hline Dummy Age 65+ & $-0.211^{*}$ & $-0.003^{*}$ & $-0.237^{*}$ & $-0.149^{*}$ \\
\hline Married & $0.439^{*}$ & $0.554^{*}$ & $-0.215^{*}$ & $-0.215^{*}$ \\
\hline $\begin{array}{l}\text { Secondary degree } \\
\text { or more }\end{array}$ & $0.147^{*}$ & $0.283^{*}$ & $0.435^{*}$ & $0.464^{*}$ \\
\hline Old Age Pensioner & & $-0.637^{*}$ & & $-0.208^{* *}$ \\
\hline *Pension size & & $-0.001^{*}$ & & -0.000 \\
\hline $\begin{array}{l}\text { *Years since } \\
\text { pension }\end{array}$ & & $-0.022^{*}$ & & -0.015 \\
\hline Survivor's pension & $\mathrm{Na}$ & $\mathrm{Na}$ & & $-0.219^{*}$ \\
\hline *pension size & $\mathrm{Na}$ & $\mathrm{Na}$ & & $-0.002^{\mathrm{m}}$ \\
\hline $\begin{array}{l}\text { *years since } \\
\text { pension }\end{array}$ & & $\mathrm{Na}$ & & -0.008 \\
\hline Unemployment rate & $-0.038^{*}$ & $-0.033^{*}$ & $-0.021^{*}$ & $-0.020^{*}$ \\
\hline \# observations & 34,070 & 34,070 & 24,978 & 24,978 \\
\hline \# individuals & 3,267 & 3,267 & 2,438 & 2,438 \\
\hline Log likelihood & -17243.404 & -16161.942 & -15413.58 & -15272.91 \\
\hline
\end{tabular}

Sample excludes disability and PASIS pensioners and non-affiliates. Std.

Err. adjusted for 2438 clusters

* significant at $0.1 \%$

** significant at $1 \%$

$* * *$ significant at $5 \%$

m marginally significant at $10 \%$ 
Figure 1A: Unadjusted work probabilities for male affiliates in our sample

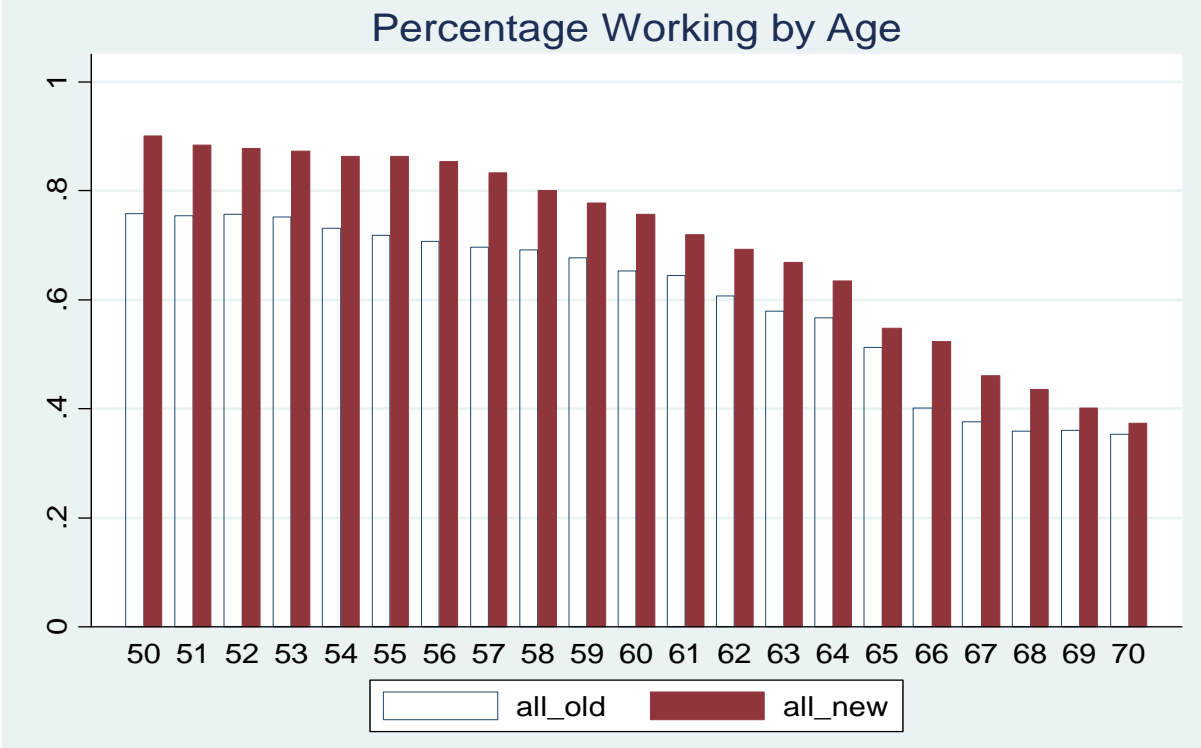

Figure 1B: Unadjusted work probabilities for female affiliates in our sample

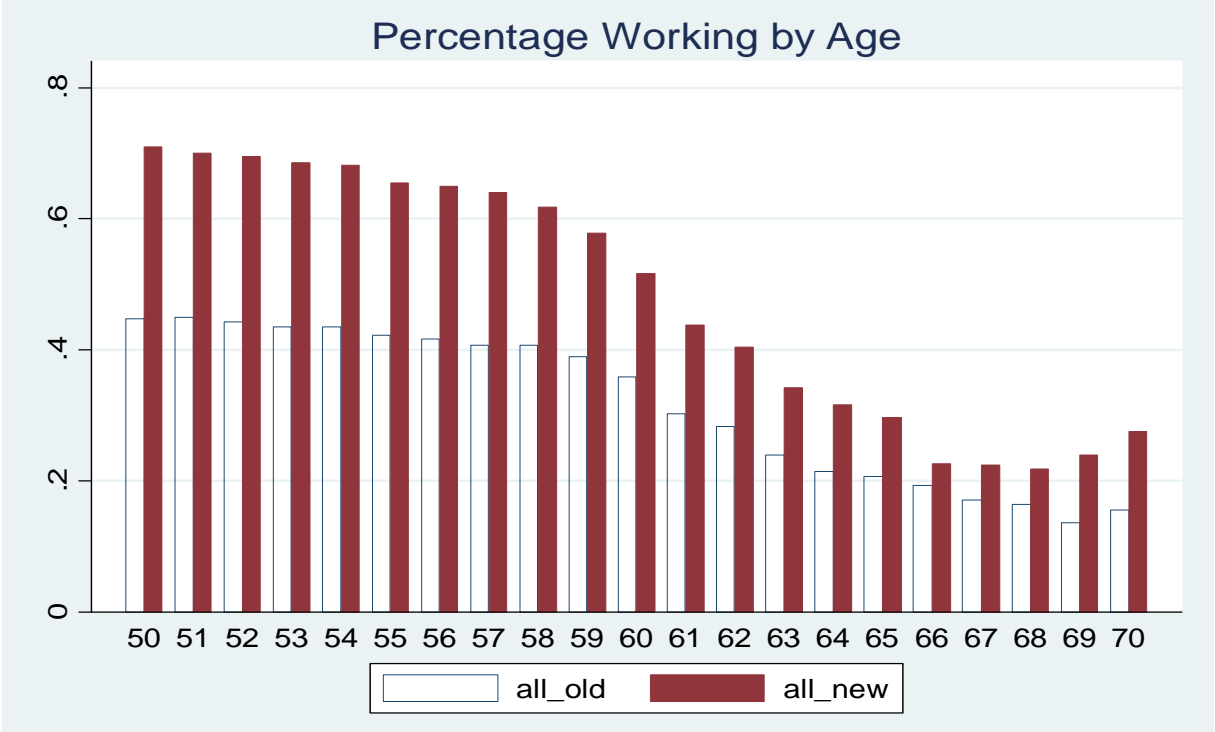


Figure 2: Male pension probabilities by age over time

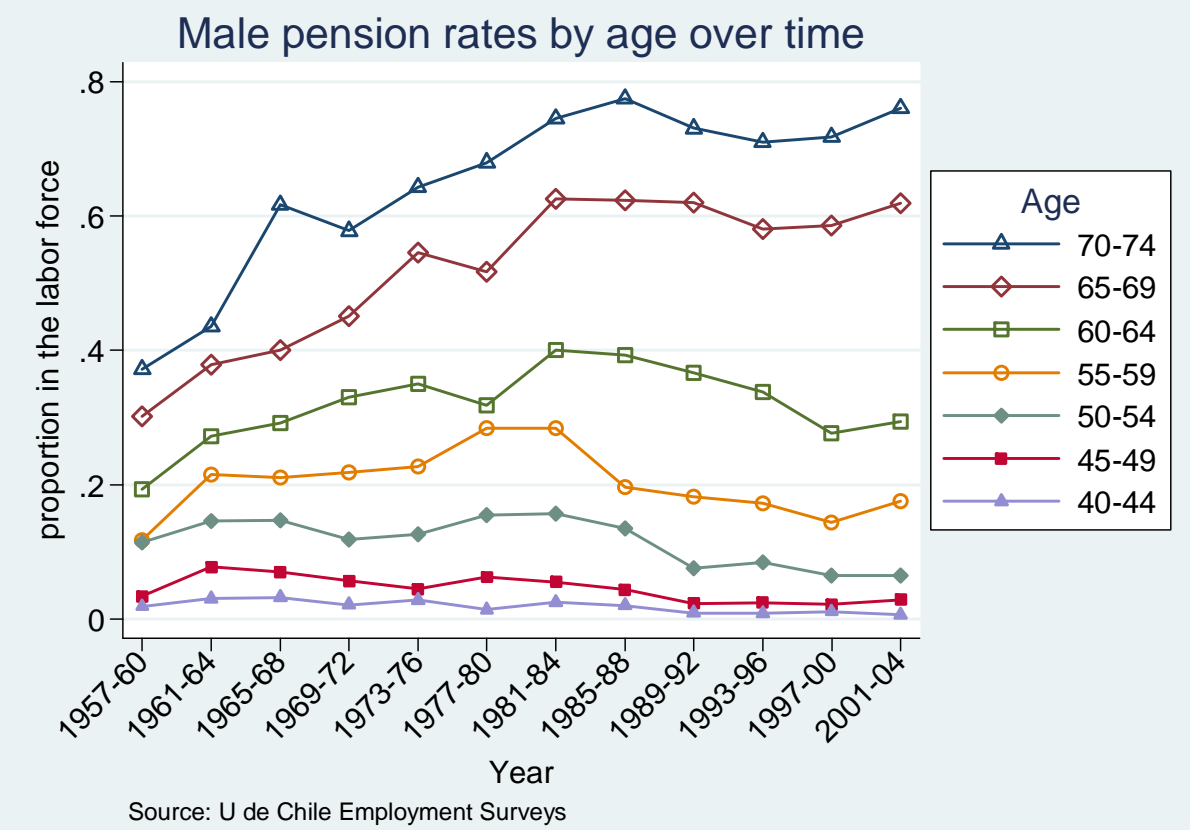

Figure 3: Labor force participation rates for older men over time—pensioners vs. non-pensioners

Male labor force participation rate by age pensioners and non-pensioners compared

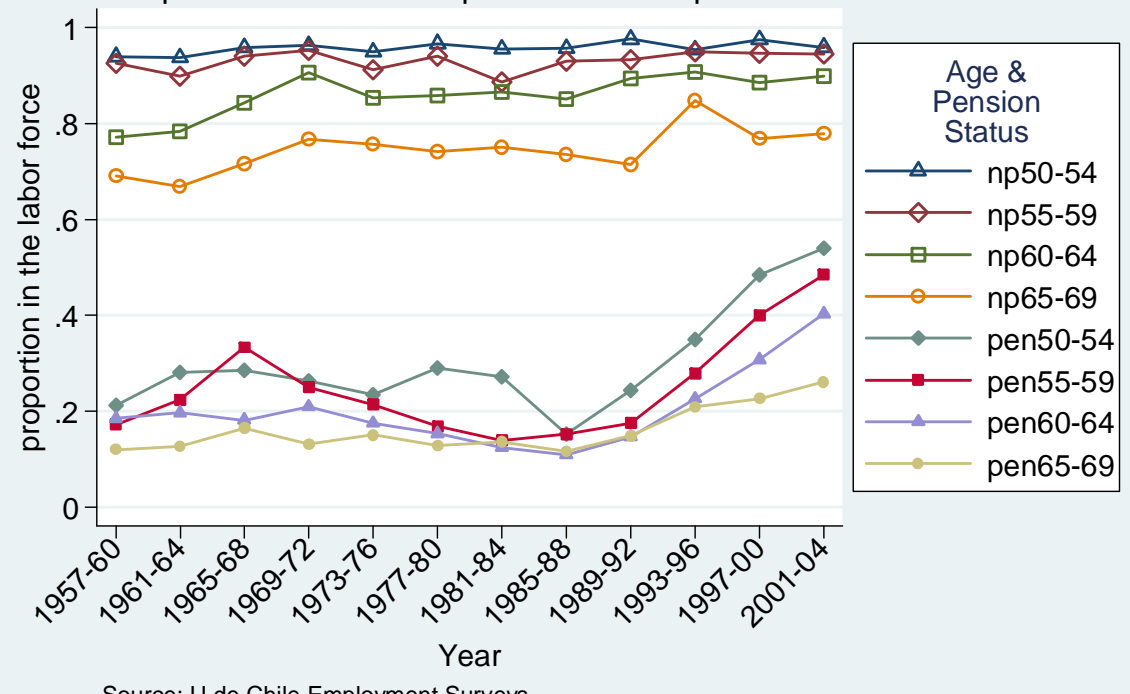

Source: $U$ de Chile Employment Surveys 


\section{References}

Anderson, Patricia, Alan Gustman and Thomas Steinmeier. 1999. "Trends in Male Labor Force Participation and Retirement: Some Evidence on the Role of Pensions and Social Security in the 1970's and 1980's." Journal of Labor Economics. 17 (4), 757-783.

Blau, David. 1994. "Labor force Dynamics of Older Men.” Econometrica. 62(1) 117-56.

Borsch-Supan. Axel. 1998. "Incentive Effects of Social Security on Labor Force Participation: Evidence in Germany and Across Europe." NBER Working paper 6780.

Burtless, Gary and Robert Moffitt. 1986. "Social Security, Earnings Tests, and Age at Retirement.” Public Finance Quarterly. 14 (1): pp. 3-27.

Butler, Monika, Olivia Huguenin and Federica Teppa. 2004. "What Triggers Early Retirement? Results from Swiss Pension Funds". Working paper. Univ. of Lausanne.

Cheyre, Hernan. 1991. "La Prevision en Chile Ayer y Hoy." Centro de Estudios Publicos. Santiago, Chile.

Coile, Courtney and Jonathan Gruber. 2001. "Social Security Incentives for Retirement." in Themes in the Economics of Aging. ed. David Wise. Chicago: Univ. of Chicago Press.

Disney, Richard. 2004. "Are contributions to public pension programmes a tax on employment?" Economic Policy. 267-311.

Disney, Richard, M. Queisser and Edward Whitehouse. 2006. Neutral, fair or something else? A taxonomy of actuarial concepts used in pension-system design. Paris: OECD.

Edwards, Sebastian and Alejandra C. Edwards 2002. "Social Security Privatization Reform and Labor Markets: The Case of Chile," Economic Development and Cultural Change 50 (3): 465-89.

Edwards, Alejandra C. and Estelle James. 2006. "Crowd-out, Adverse Selection and Information in Annuity Markets: Evidence from a new retrospective data set in Chile." MRRC Working Paper 2006-147 (UM06-19).

Edwards, Alejandra and Estelle James. 2008. "Do Individual Accounts Postpone Retirement: Evidence from Chile?” MRRC Working Paper 2005-098 (UM04-07).

Fields, Gary and Olivia Mitchell. 1984. Retirement, Pensions and Social Security. Cambridge, MA.: MIT Press.

Friedberg, Leora. 2007. "The Recent Trend Toward Later Retirement." Center for Retirement Research, Boston College, Series 9.

Gruber, Jonathan and David A. Wise eds. 1999. Social Security and Retirement Around the World. Chicago: University of Chicago Press.

Gruber, Jonathan and David A. Wise eds. 2004. Social Security Programs and Retirement Around the World: Micro-Estimation. Chicago: University of Chicago Press. 
Gruber, Jonathan (1997): "The Incidence of Payroll Taxation: Evidence from Chile," Journal of Labor Economics 15 ( Part 2): S72-S101.

Gustman, Alan and Thomas Steinmeier. 1985. "The 1983 Social Security Reforms and Labor Supply Adjustments of Older Individuals in the Long run." Journal of Labor Economics. 3 (2); 237-252.

Hurd, Michael. 1990. "Research on the Elderly: Economic Status, Retirement, and Consumption and Saving." Journal of Economic Literature. 28 (2). 565-637.

James, Estelle, Guillermo Martinez and Augusto Iglesias 2006. "The Payout Stage in Chile: Who Annuitizes and Why?"Journal of Pension Economics and Finance. 5(2)121-54.

James, Estelle, Alejandra Cox Edwards and Augusto Iglesias. 2009. "The Impact of Private Participation and Countervailing Information on Disability Costs: Evidence from Chile." Journal of Pension Economics and Finance, 2009 forthcoming.

Krueger, Alan and Jorn-Steffan Pischke. 1999. "The Effect of Social Security on Labor Supply: A Cohort Analysis of the Notch Generation". Journal of Labor Economics 10 (4):412-37.

Lluberas, Rodrigo. "Labour Supply of Older Workers in the UK: Is there a Link with Pension Provisions?" Watson Wyatt Technical Research Paper No. 11/2007.

Meghir, Costas and Edward Whitehouse. 1997. "Labour Market Transitions and Retirement of Men in the UK." Journal of Econometrics. 79:327-54.

Palacios, Robert and Edward Whitehouse. 1998. "The Role of Choice in the Transition to a Funded System.” SP Discussion Paper No. 9812. World Bank.

Pang, Gaobo, Mark Warshawsky and Ben Weitzer, "The Retirement Decision: Current Influences on the Timing of Retirement among Older Workers." Pension Reserach Council WP2008-04, University of Pennsylvania.

SAFP. (Superintendencia de Administradoras de Fondos de Pensiones). 2003. The Chilean Pension System. Santiago, Chile.

Stock, James and David Wise. "Pensions, the Option Value of Work, and Retirement". Econometrica 58 (5): 1151-80.

Song, Jae G. and Joyce Manchester. 2006. "New Evidence on Earnings and Benefits Claims Following Changes in the Retirement Earnings Test in 2000." ORSE Working Paper No. 107. Washington DC: Social Security Administration. 


\section{Endnotes}

${ }^{1}$ For preliminary descriptive statistics on labor supply impact see Edwards and Edwards (2002). Gruber (1997) studied the incidence of the payroll tax in Chile. Edwards and James 2008 used birth cohort as a proxy for new system membership and studied changes over time in labor force participation of older workers, as the new system was phased in.

2 These descriptions are based on SAFP 2003, Cheyre 1991 and personal communications with Augusto Iglesias, Primamerica Consultores.

${ }^{3}$ While employers paid $2 / 3$ of the $23 \%$ tax in the old system, workers pay the entire tax in the new system, an increase from $7.25 \%$ to $12.5 \%$ of wages. In the short run, wage increases were legally required for workers who switched, to compensate for the tax saving to employers and new tax paid by workers. In that case, gross and net wages would have increased. We don't know how effectively that requirement was implemented or how markets responded to the changed tax rate. Real wages have risen, on average, about $2 \%$ per year over the last 25 years.

${ }^{4}$ There were some variations by sub-system. Retirement age was even lower before the old system was reformed, for fiscal reasons, in the late 1970's. Early retirement and evasion resulted in a contributor/ pensioner ratio of 2.2 in 1980, lower than in the U.S. today, despite a much younger population in Chile.

${ }^{5}$ Although these restrictions appear to be high, the majority of pensioners since 1988 have been early pensioners, consistent with our expectation that most individuals will start their pension as soon as possible. The implied age of eligibility varies widely across individuals, so we do not expect bumps in retirement at any particular point until age 65 .

${ }^{6}$ More precisely, if the individual has annuitized his or her retirement accumulation and the MPG rises above the annuity level, the government tops up the annuity. If, in contrast, the individual has taken gradual withdrawals from his or her account, the government requires that these withdrawals must be at least equal to the MPG level, and once the account is used up the treasury pays the entire pension.

${ }^{7}$ In 2008 the government has recently started replacing the MPG with a means-tested basic benefit that will be targeted toward the $60 \%$ poorest households in the economy, including non-contributors, creating yet another set of incentives. We reserve this topic for further investigation using a different data set and focus on the broader incentives outlined above, in this paper. The entire period of this analysis was prior to 2008 .

${ }^{8}$ For example: a worker may be forced to save at a higher rate than he would prefer; he wishes to start his pension sooner than the retirement age rules permit; he wishes to use his saving to cover emergency or other consumption in the early years of retirement; he prefers to invest in different ways from those permitted by regulations. Until 2002 workers had a choice of investment manager but virtually no choice of investment strategy. Since 2002 greater choice of investment options has been allowed but this is still limited to 4 or 5 portfolios. Workers who wish to put all their funds into stocks or foreign investments are not allowed to do so. Investment options during the payout phase are 
even more tightly constrained. Until 2004 only fixed annuities or gradual withdrawals based on conservative investments were allowed. Individuals who are in ill-health may not expect to get back their full premiums through annuities or gradual withdrawals.

${ }^{9}$ The estimate of a 50\% implicit tax is based on wage differentials between workers who pay the payroll tax and get benefits versus those who don't (Edwards and Edwards 2002). For a related UK analysis see Disney 2004.

10 Several forces in the new system may counteract this tax wedge and lead to some postponement of pensioning. Non-pensioners who contribute get access to disability and survivors insurance at a community rate that is advantageous (below true risk cost) for older workers; they lose this access once they start their pension. Retirees will be entitled to a higher minimum pension guarantee if they start their pension later; therefore workers who expect low pensions will gain if they postpone pensioning. Those with less than 20 years of contributions may delay pensioning until they meet this condition for eligibility for the MPG. Finally, pensions are taxable so postponing pensions also postpones taxes.

11 The 2006 survey was actually carried out between October 2006 and March 2007. Therefore, in the cohort born 1956 we are including individuals born up to March 1957, who turned 50 up to March 2007, and similarly for other cohort and age groups.

Individuals who died before 1982 were not included in the sample frame. Those who died after 1982 were included, and information about them was obtained from system records and relatives. We omitted dead individuals from our analysis because of missing information. This probably resulted in an under-representation of old system members, who tended to be older and therefore more likely to die. However, there is no reason to believe that this omission biased our results. For a fuller discussion of deaths and survival bias in an analysis of disability hazards, where it potentially biased the results, see James, Edwards and Iglesias 2009.

12 Being out of the labor force in period 1 increases the likelihood of being out in period 2 , and this likelihood and inter-period correlation increase with age, but nevertheless, individuals move in and out of spells of employment and non-employment until age 65 and beyond. (See Meghir and Whitehouse 1997 for an analysis of detailed British data on this subject). We treat each year as independent.

13 In follow-up work we plan to analyze the 2006 cross-section in greater detail, adding individual-specific variables for which we do not have year-by-year information, such as number of children, spousal age differential, whether the spouse worked or was pensioned, household income per capita, other saving, health status and knowledge about the system. We plan to investigate, in particular, whether health status and knowledge influence system choice and new-system effect.

14 We alternatively measured education as a continuous variable-years of schooling. The reform impact was very similar in both cases. Besides the cross-sectional differences among individuals at a point in time, Major changes in educational levels took place in Chile over the lifetime of the individuals in our study, especially for women. For example, $80 \%$ of all women aged 16-65 has less than full secondary education in 1970 
but this proportion had fallen to $44 \%$ by 2000 . Therefore, educational levels differed widely across affiliates of different ages and cohorts, in our sample.

15 A number of other factors, not directly related to age or expected participation rates, also entered into the decision. For example, workers in less generous old system programs (with lower replacement rates or longer service required for a full pension) would be more likely to switch. Those who had optimistic expectations about future investment returns were more likely to switch. And employers sometimes encouraged switching, because this would free them of the $23 \%$ payroll tax.

16 Part of the effect for women may still be due to the correlation between the numerator and denominator of this term-women's aggregate labor force participation rate increased during the period 1981-2006 due to changing education and social norms, over the same period when new-system membership was increasing.

${ }^{17}$ Consistent with these findings, removal of the retirement earnings test (a high implicit tax rate on pensioner wages) has produced a large increase in work propensities of older individuals in the DB system in the U.S. See Song and Manchester 2006. Sweden's notional DC plan, Germany's point system and Finland's defined benefit scheme have tied monthly benefit amount to life expectancy but they have not tied retirement age to benefit amount, except on a voluntary basis.

18 On average, replacement rates were falling during the post-reform period, because wages were rising faster than pensions. Also, monthly payouts on new annuity contracts decrease as longevity increases. This might have exerted a positive impact on participation rates. We cannot include replacement rates in these data, because we don't know the individual's previous wage rate. 